Journal of Volcanology and Geothermal Research

August 2016, Volume 322, Pages 30-47

http://dx.doi.org/10.1016/i.jvolgeores.2016.02.026

http://archimer.ifremer.fr/doc/00319/43052/

(c) 2016 Elsevier B.V. All rights reserved.

\title{
Temporal magma source changes at Gaua volcano, Vanuatu island arc
}

\author{
Beaumais Aurélien ${ }^{1,2,{ }^{*} \text {, Bertrand Hervé }}{ }^{3}$, Chazot Gilles ${ }^{1}$, Dosso Laure ${ }^{4}$, Robin Claude ${ }^{5}$
}

\begin{abstract}
${ }^{1}$ CNRS-UMR6538, Domaines Océaniques, Institut Universitaire Européen de la Mer, Université de Bretagne Occidentale, Place Copernic, 29280 Plouzané, France

${ }^{2}$ Ocean and Earth Science, National Oceanography Centre Southampton, University of Southampton, European Way, Southampton SO14 3ZH, UK

${ }^{3}$ Laboratoire de Géologie de Lyon, CNRS-UMR 5276, Université Claude Bernard and ENS Lyon, 69364 Lyon, France

${ }^{4}$ CNRS-UMR6538, Ifremer, Département Géosciences Marines, 29280 Plouzané, France

${ }^{5}$ Laboratoire Magmas et Volcans, Université Blaise Pascal, CNRS-UMR 6524, IRD-unité R163,

Clermont-Ferrand, France

*Corresponding author : Aurélien Beaumais, email address : aurelienbeaumais@hotmail.fr
\end{abstract}

\begin{abstract}
:
Gaua Island (also called Santa Maria), from the central part of the Vanuatu arc, consists of a large volcano marked by a caldera that hosts the active Mount Garet summit cone. In this paper, a geochemical study including $\mathrm{Sr}, \mathrm{Nd}, \mathrm{Pb}$ and $\mathrm{Hf}$ isotopic compositions of 25 lavas emitted since $1.8 \mathrm{Ma}$ is presented, with a focus on the volcanic products that preceded (old volcanics, main cone and pyroclastic series) and followed (Mount Garet) the caldera forming event.

All lavas show an island arc signature with enrichment in LILE and depletion in HFSE. Post-caldera lavas define a medium- $\mathrm{K}$ calc-alkaline trend, whereas lavas from the former main cone have high- $\mathrm{K}$ calc-alkaline compositions. Compared to the pre-caldera volcanic suite, the Mount Garet lavas have similar $\mathrm{Th} / \mathrm{Nb}(\sim 1.5), 143 \mathrm{Nd} / 144 \mathrm{Nd}(\sim 0.51295)$ and $176 \mathrm{Hf} / 177 \mathrm{Hf}(\sim 0.28316)$ ratios, but higher Ba/La $(\sim 42$ vs. $\sim 27)$ and $87 \mathrm{Sr} / 86 \mathrm{Sr}(0.70417$ vs. 0.70405$)$ ratios and lower Ce/Pb ( 2.7 vs. $~ 4.6), \mathrm{La} / \mathrm{Sm}(\sim$ 2.5 vs. $\sim 4.0)$ and $206 \mathrm{~Pb} / 204 \mathrm{~Pb}(18.105$ vs. 18.176) ratios. High $\mathrm{Th} / \mathrm{Nb}$ and low $\mathrm{Nd}$ and $\mathrm{Hf}$ isotopic ratios compared to N-MORB suggest the contribution of $\sim 2 \%$ of subducted sediment melt to the mantle source of Gaua magmas. Most of the observed differences between pre- and post-caldera lavas can be accounted for by the involvement of at least two portions of the mantle wedge, metasomatized by different slab-derived aqueous fluids. In addition, the lower $\mathrm{La} / \mathrm{Sm}$ (at a given $143 \mathrm{Nd} / 144 \mathrm{Nd}$ ) ratios of Mount Garet lavas suggest a higher degree of partial melting ( 10-15\%) compared to the pre-caldera lavas ( 5\%). The Santa Maria Pyroclastic Series (SMPS) eruption probably triggered the caldera collapse, in response to emptying of the magmatic chamber. This event may have allowed new access to the surface for a geochemically distinct batch of magma issued from a separate magma chamber, resulting in the birth and construction of Mount Garet within the caldera. As both magmatic suites were emitted over a very short time, the storage of their parental magmas beneath the volcano is still possible.
\end{abstract}




\section{Highlights}

- New Hf-Pb isotopes and geochemical study of Gaua, on pre- and post-caldera lavas $>$ Post-caldera lavas are geochemically distinct from older lavas. Evidences of short-term changes in the mantle source - Involvement of different metasomatic agents and variable degrees of partial melting Pyroclastic Series eruption triggered caldera collapse and gave access to new magma.

Keywords : Gaua, Vanuatu, Geochemistry, Isotopes, Subduction, Mantle source

\section{Introduction}

Space-time variations in the geochemistry of lavas are commonly observed across and/or along island arcs (Wilson, 1989). For example, the K2O composition of lavas increase from the front-arc towards the back-arc due to changing mantle sources and petrogenetic processes related to an increase in slab depth (Dickinson, 1970). Moreover, distinct trace element contents and isotopic signatures of arc lavas are in part related to various metasomatism of the mantle wedge due to fluids (e.g. high $\mathrm{Ba} / \mathrm{Th}$ and low $87 \mathrm{Sr} / 86 \mathrm{Sr}$ ) and/or sediment melts (e.g. high La/Sm and low $143 \mathrm{Nd} / 144 \mathrm{Nd}$ ) released by the subducting slab (e.g. Elliott, 2003 ; Labanieh et al., 2012). The Vanuatu arc, with fast rates of subduction and variations of the 
subduction velocity along the arc as well as a blocked zone around d'Entrecasteaux (e.g. Calmant et al., 2003), is an exceptional example of a modern day intra-oceanic subduction. How this feature affects the geochemistry of the arc and what the geochemistry can provide to further our understanding on this specific zone and subduction volcanoes, in general, are relevant questions. At the island scale, the exposed lavas at Gaua volcano vary from mediumto high-K calc-alkaline series during Holocene times. This feature is not unique, and both signatures are recorded in other Vanuatu islands, such as Ambrym, Erromango (Monzier et al., 1997; Peate et al., 1997) and in volcanic complexes from other island arcs (Francalanci et al., 1989; Edwards et al., 1994; Calanchi et al., 2002; Gertisser and Keller, 2003; Francalanci et al., 2014). These authors explain such variations by: (1) The involvement of several compositionally distinct mantle sources which sustained variable degrees of partial melting, (2) the addition of variable amounts of sediment to the mantle wedge and (3) a combination of fractional crystallization, crustal assimilation and magma mixing. Gaua Island is therefore a relevant case study to investigate the relationships between distinct arc series and the role of intracrustal and mantle wedge processes. In this paper, we report the first comprehensive geochemical and isotopic ( $\mathrm{Sr}, \mathrm{Nd}, \mathrm{Pb}, \mathrm{Hf}$ ) analyses of samples from Gaua. The data are used to constrain the magmatic differentiation processes within the volcanic system and the temporal changes in mantle sources tapped by the volcano.

\section{Geological setting and previous works}

\subsection{Geological setting}

The Vanuatu active arc stretches along $1200 \mathrm{~km}$ in the Southwest Pacific from Ureparapara in the north to Hunter in the south and is located in a complex convergent boundary between the Australian and Pacific plates (Fig. 1). The convergence is marked by two opposite subduction zones, defined by the Vanuatu trench to the west and the Tonga trench to the east, resulting in 
an asymmetric opening of the North Fiji back-arc basin for $~ 12$ Ma (Auzende et al., 1995).

Since $7 \mathrm{Ma}$, the Australian plate has subducted underneath the North Fiji basin, giving birth to the Vanuatu active arc 6 Ma ago (MacFarlane et al., 1988). Currently, the convergence rate reaches $12 \mathrm{~cm} / \mathrm{yr}$ at the northern part of the West Torres plateau (WTP), but is only $3.5 \mathrm{~cm} / \mathrm{yr}$ near the D'Entrecasteaux ridge (DER) collision zone (Calmant et al., 2003).

Gaua Island, also called Santa Maria, has been an active composite-volcano since 1.8 Ma (Mallick and Ash, 1975; MacFarlane et al., 1988 ; Monjaret, 1989). Gaua volcano is located on the northern margin of the subsiding North Aoba (intra-arc) basin (Fig. 1) and belongs to the central block of the Vanuatu active arc (Monzier et al., 1997; Calmant et al., 2003). This area is tectonically influenced by the impingement of the D'Entrecasteaux Ridge (DER) and the West Torres Plateau (WTP) with the Vanuatu arc (Taylor, 1992; Meffre and Crawford, 2001). The central block is currently shifted eastward and thrust on the North Fiji basin along the Back-Arc Thrust Belt (BATB) (Calmant et al., 2003), whereas the northern and southern blocks are rotating in opposite directions and are associated with the opening of back-arc troughs (Jean Charcot and Coriolis trough). Gaua volcano, located $\sim 135 \mathrm{~km}$ to the east of the trench, and $200 \mathrm{~km}$ above the Australian slab roof (Monzier et al., 1997; Syracuse and Abers, 2006), is built on the thin (11-13 km) North Aoba basin crust (Pontoise et al., 1994).

\subsection{Geology of Gaua volcano}

Gaua island corresponds to the emerged part of a $2500 \mathrm{~m}$-high and $45 \mathrm{~km}$-wide composite volcano and mainly consists of a little-dissected cone (Fig. 2) about $22 \mathrm{~km}$ in diameter, truncated between 500 and $700 \mathrm{~m}$ of altitude by a 8.5 x $6 \mathrm{~km}$ central caldera. The caldera hosts the crescent-shaped Lake Letas and the $3 \mathrm{~km}$ wide active Mt Garet which peaks $468 \mathrm{~m}$ above the lake. Mallick and Ash (1975) presented the first detailed account of the geology of Gaua (Fig. 2), which was revised by Robin et al. (1995). 
Pre-caldera stage. A large sub-aerial edifice (the Old Edifice, unit 1 on Fig. 2), mainly basaltic in composition, grew during Pliocene times, forming the exposed basement of Gaua island, and confined on two high ridges in the southwest corner of the island (Burilan, Devil Rock, Lakona Bay, Olimbu). Its growth probably ceased in the early Pleistocene. Over the remnants of this former edifice, the Main Cone (unit 2 on Fig. 2) formed during the Holocene, consisting of a thick subaerial pile of basaltic and andesitic lava flows. This volcanic series appears along the coast, the caldera wall and in the incised Lusal river channel (SM57 sample on Figure 2).

$\underline{\text { Syn-caldera stage. }}$ On the lower slopes, an extensive series of mafic ash and scoria flows (unit 3 on Fig. 2) has been identified as the Santa Maria Pyroclastic Series (SMPS, Robin et al., 1995). Along the southern coast, cliffs expose a composite sequence of pyroclastic deposits which overlie volcanics of the pre-caldera edifice. In the north (sites 13 to 17, Fig. 2), at least three thick, indurated pyroclastic flows are interbedded with fallout tephra and thinner beds of pyroclastic flows - overlain by fall deposits - forming a complex sequence about $60 \mathrm{~m}$ in thickness. No buried soil has been observed between the successive flow units, which were probably emplaced in a short time interval. The pyroclastic flows consist of fine and coarse ash including glass lapilli, dense scoria bombs, pumice and lithic fragments. The Lusal River (East flank) provides another outcrop which confirms that $\sim 30-40 \mathrm{~m}$ thick ash deposits, previously reported by Mallick and Ash (1975), cover a nearly circular area 7-8 km in radius from the center of the volcano. Dacitic obsidian blocks have also been documented in association with the Santa Maria Pyroclastic Series. However, their origin is not well constrained and they could have been emitted during a pre-caldera stage (Métrich et al. this volume). The large volume $\left(6.5-7 \mathrm{~km}^{3}\right)$ of Santa Maria Pyroclastic Series, which blankets the pre-caldera effusive cone, led Robin et al. (1995) to reconsider the caldera formation in terms of explosive dynamics contrasting with a process of quiet subsidence proposed by Mallick and Ash (1975). In the model of Robin et al. (1995), the emission of voluminous pyroclastic flows through the central vent during a major hydromagmatic event provoked: (1) The partial emptying of a compositionally layered but mainly basaltic reservoir and (2) the collapse of the 
upper part of the volcano. On the flanks, small parasitic cones and fissure-fed lava flows (unit 4 on Fig. 2) are distributed along concentric fractures around the caldera rim and probably developed during a late stage of caldera formation. Based on mineralogical and geochemical features, these lateral emissions of basalts and andesites are thought to have erupted from the same reservoir as the main pyroclastic event (Fig. 2). Very little evidence of dissection in the vents and lava surfaces covering the lower slopes suggests that these peripheral extrusions are very young. The exact age of caldera formation is so far unknown but is probably less than 10,000 years old.

Post-caldera stage. Since the formation of the caldera, volcanic activity on the island has continued through a series of eruptions emanating from the young, active Mount Garet (unit 5 on Fig. 2), which was built within the caldera. Mount Garet is composed of three successive units: (1) A basal edifice with interbedded lava flows and tuffs, (2) an intermediate tuff cone and (3) a cap of lava flows that are more developed on the southeastern slopes (Fig. 3). A small plateau, carved by three inactive pit craters (the northern one corresponding to a small maar), forms the summit of Mount Garet. Basaltic cinder beds, lava flows and dykes are exposed along the walls of these craters. The active vent is on the southeast slope of the cone, just below the plateau, and its crater walls expose several basaltic lava flows. Some hydrothermal activity is recorded as discoloration of Lake Letas (Fig. 3). No eruptions were recorded until 1962, when the western flank of the cone defoliated. The creation of a new crater on the southeast flank followed in 1963, associated with the emission of a dark, grey ash column. The last intense explosive activity was recorded in 2009-2010 (Bani et al., 2015; Métrich et al., 2015).

\subsection{Previous geochemical work}

Compared to other Vanuatu volcanoes, lavas from Gaua have elevated abundances of $\mathrm{K}_{2} \mathrm{O}$, large ion lithophile elements (LILE such as $\mathrm{Rb}, \mathrm{Ba}, \mathrm{K}, \mathrm{Pb}, \mathrm{Sr}$ ) and light rare earth elements (LREE), displaying some of the strongest enrichments of these incompatible elements 
observed in the archipelago (Monzier et al., 1997; Peate et al., 1997). They also have lower ${ }^{143} \mathrm{Nd} /{ }^{144} \mathrm{Nd}$ and ${ }^{206} \mathrm{~Pb} /{ }^{204} \mathrm{~Pb}$ ratios than most lavas from the active Vanuatu arc (Briqueu and Lancelot, 1983; Briqueu et al., 1994; Peate et al., 1997; Laporte et al., 1998; Turner et al., 1999). These distinctive features were previously ascribed as a consequence of the collision of the D'Entrecasteaux ridge (Peate et al., 1997; Turner et al., 1999), or from the assimilation of an old continental crust in accordance with the recent discovery of pre-Cenozoic (280-220 Ma) zircons from igneous rocks sampled on the old Vanuatu Western Belt (Buys et al., 2014). In addition, drastic changes in the geochemical signature (major and trace elements) from preand syn-caldera lavas to post-caldera lavas (Mount Garet) characterize Gaua Island as highly depleted in $\mathrm{K}_{2} \mathrm{O}$ compared to younger volcanoes (Robin et al., 1995).

\section{Sampling and analytical techniques}

Eighty-four samples from lava and pyroclastic flows, belonging to different volcanic phases, were collected from Gaua Island during the "VOLVAN" (Volcanism of Vanuatu) project, led by ORSTOM (now IRD, the Research Institut for Development) in July 1992. These samples were described and analysed for major and trace elemental abundances by Robin et al. (1995). We selected twenty-five samples from different volcanic phases (old massif, main cone, pyroclastic series, parasitic cones and Mount Garet) that encompass compositions ranging from basalt to dacite to perform new isotopic and trace element analyses.

\subsection{Major and trace elements}

Mineral and major element compositions are given in Robin et al. (1995). Whole-rock analyses of trace element concentrations were determined in solution by HR-ICP-MS Thermo Fisher Element-II® (IUEM, Plouzané), using the procedures described by Chauvel et al. (2011). Trace element concentrations were calculated using a machine drift correction based on a 3-element (Be, In, Tm) spike with a mass-based interpolation. Precision for most 
elements is better than $2 \%$ RSD. Accuracy is better than $5 \%$ for most elements relative to suggested values for international standards BCR-2 (Jochum and Brueckner, 2008) and JB-2 (Barrat et al., 2012) (Table 1). Major and trace elements from sample GA21 were analysed by the SARM-CRPG Nancy (Métrich et al., this volume).

\subsection{Isotopes}

23 samples were analysed for $\mathrm{Pb}, \mathrm{Sr}, \mathrm{Nd}$ and $\mathrm{Hf}$ isotopes. Chemical separation for isotopic measurements was carried out in a clean room (PSO - Pole Spectrometry Ocean, Plouzané, France).

From a single sample digestion, we used a combined procedure for separating $\mathrm{Pb}, \mathrm{Sr}, \mathrm{Nd}$, and Hf in 5 steps of chromatography: (1) About $700 \mathrm{mg}$ of whole rock powder was dissolved for $72 \mathrm{~h}$ with a 3:1 concentrated $\mathrm{HF}-\mathrm{HBr}$ mixture in teflon Savillex ${ }^{\circledR}$ beakers at about $80^{\circ} \mathrm{C}$ and evaporated to dryness. Six samples (SM2A-SM8A-SM8E-SM8B-SM13A-SM17D) were crushed at granular gravel size (see caption, Table 1) and $700 \mathrm{mg}$ were leached with concentrated $\mathrm{HBr}$ for 5 min under ultrasonic conditions before dissolution. (2) $\mathrm{Pb}$ was first separated from other elements using the classical $\mathrm{HBr}$ anion-exchange resin technique (AG1X8 100-200 mesh) of Manhès et al. (1984). (3) The Pb-free fraction was loaded onto a 6.5 $\mathrm{cm}^{3}$ cation-exchange resin BioRad ${ }^{\circledR}$ (AG50-8X 200-400 mesh) column to separate the High Field Strength Elements (HFSE) using mixed 0.5M HCl /0.15M HF, Sr with 3M HCl, and rare earth elements (REE) with 3.6 $\mathrm{M} \mathrm{HNO}_{3}$. (4) $\mathrm{Hf}$ was further separated from Ti using a modified version of the method described by Yang et al. (2010). Briefly, the HFSE fraction was loaded onto a column filled with $100 \mathrm{mg}$ of Eichrom ${ }^{\circledR}$ Ln-resin. Ti was removed with $15 \mathrm{~mL}$ of a $6 \mathrm{M}$ $\mathrm{HCl}-\mathrm{H}_{2} \mathrm{O}_{2}$ mixture and the $\mathrm{Hf}-\mathrm{Zr}$ fraction was eluted with $2 \mathrm{~mL}$ of $2 \mathrm{M} \mathrm{HF}$. (5) Finally Nd was isolated from other REE using the Eichrom ${ }^{\circledR}$ Ln-resin technique adapted from Richard et al. (1976) with dilute $\mathrm{HCl}$. Total procedural chemistry blanks during the course of this work were less than $71 \mathrm{pg}$ for $\mathrm{Hf}, 58 \mathrm{pg}$ for $\mathrm{Nd}, 557 \mathrm{pg}$ for $\mathrm{Sr}$, and $120 \mathrm{pg}$ for $\mathrm{Pb}$. These values are negligible relative to the amount of each element present in the samples. 
$\mathrm{Sr}$ and $\mathrm{Nd}$ isotope ratios were measured in static mode using a solid source Thermo Fisher ${ }^{\circledR}$ Triton TI-MS (Thermal Ionization - Mass Spectrometer) at PSO- IUEM. All measured ratios were corrected for fractionation using ${ }^{88} \mathrm{Sr} /{ }^{86} \mathrm{Sr}=8.3752$ and ${ }^{146} \mathrm{Nd} /{ }^{144} \mathrm{Nd}=0.7219$. The average ${ }^{87} \mathrm{Sr} /{ }^{86} \mathrm{Sr}$ ratio measured for the NBS 987 standard was $0.710271 \pm 14$ (2SD, for 12 runs) on the Triton. The average ${ }^{143} \mathrm{Nd} /{ }^{144} \mathrm{Nd}$ ratio measured for the JNdi-1 standard was $0.512105 \pm 12$ (2SD, for 13 runs) and $0.511846 \pm 7$ (2SD, for 6 runs) for the La Jolla standard. $\mathrm{Pb}$ and $\mathrm{Hf}$ isotopic ratios were measured using a Thermo Fisher® Neptune MC-ICP-MS (Multi Collector - Inductively Coupled Plasma - Mass Spectrometer) at PSO-IUEM. The Hf mass bias was corrected using an exponential law and assuming a ${ }^{179} \mathrm{Hf} /{ }^{177} \mathrm{Hf}$ ratio of 0.7325 . The average ${ }^{176} \mathrm{Hf} /{ }^{177} \mathrm{Hf}$ ratio measured for the JMC475 was $0.282152 \pm 11$ (2SD, for 58 runs). $\mathrm{Pb}$ isotopic ratios were measured using the thallium addition technique in order to correct for mass bias (White et al., 2000). The NIST981 standard was run every two to three samples to correct all $\mathrm{Pb}$ isotopic ratios by standard bracketing with the value recommended by Galer and Abouchami (1998). The average ${ }^{206} \mathrm{~Pb} /{ }^{204} \mathrm{~Pb},{ }^{207} \mathrm{~Pb} /{ }^{204} \mathrm{~Pb},{ }^{208} \mathrm{~Pb} /{ }^{204} \mathrm{~Pb}$ ratios measured for the NIST981 were respectively $16.930 \pm 3,15.483 \pm 4$ and $36.670 \pm 12$ (2SD, for 29 runs).

\section{Results}

\subsection{Mineralogy}

Most samples appear fresh in thin section. A few samples show evidence for post-eruptive alteration (olivine with iddingsite rims and rarely altered pyroxenes). The mineral compositions are given by Robin et al. (1995).

\subsubsection{Old edifice and Main Cone}

The basaltic samples from the old edifice are highly porphyritic, poorly to highly vesiculated, with a glassy to fine grained groundmass, whereas the andesites are phenocryst free. The basalts contain millimeter-sized phenocrysts of clinopyroxene $\left(\mathrm{En}_{44-45}, \mathrm{Wo}_{45-49}, \mathrm{Fs}_{7-10}\right)$, olivine 
$\left(\mathrm{Fo}_{64-76}\right.$, sometimes with an iddingsite rim), and plagioclase $\left(\mathrm{An}_{40-63}\right)$, whereas the andesites contain phenocrysts of clinopyroxene, plagioclase, and slightly altered, small olivine crystals. Basalts and basaltic andesites from the Main Cone bear compositionally similar olivine $\left(\mathrm{Fo}_{57-}\right.$ 71) and clinopyroxene $\left(\mathrm{En}_{41-45}, \mathrm{Wo}_{44-52}, \mathrm{Fs}_{5-15}\right)$ phenocrysts whereas plagioclase compositions are different, ranging from $\mathrm{An}_{82-90}$ in basalts to $\mathrm{An}_{40-69}$ in basaltic andesites. Andesites are mostly olivine-free, containing phenocrysts of clinopyroxene $\left(\mathrm{En}_{38-45}, \mathrm{WO}_{45-48}, \mathrm{Fs}_{7-15}\right)$ and plagioclase $\left(\mathrm{An}_{36-62}\right)$. The groundmass of mafic samples from the old edifice and Main Cone contain microlites of clinopyroxene, plagioclase and Fe-Ti oxide in basic samples, whereas the microlites of clinopyroxene are not commonly found in the groundmass of the andesites.

\subsubsection{Pyroclastic series and parasitic cones}

The mineralogy of lavas from the pyroclastic series and parasitic cones is very similar. The only differences between the centrally (SMPS) and laterally emitted lavas (parasitic cones) concern their phenocryst abundance. Most juvenile clasts from the pyroclastic series are aphyric or crystal-poor ( $<6$ vol. \%) compared to 8-22 vol. \% for lava flows from the parasitic cones. Mineral zoning is more developed in phenocrysts from the cone series. Basalts have (sub-)euhedral phenocrysts of olivine $\left(\mathrm{Fo}_{65-75}\right)$, clinopyroxene $\left(\mathrm{En}_{42-45}, \mathrm{Wo}_{48-49}, \mathrm{Fs}_{7-10}\right)$, and plagioclase $\left(\mathrm{An}_{55-88}\right)$, whereas basaltic-andesites and andesites contain phenocrysts of olivine (Fo59-70, only in basaltic-andesites), clinopyroxene $\left(\mathrm{En}_{40-43}, \mathrm{Wo}_{43-48}, \mathrm{Fs}_{8-15}\right)$, and plagioclase $\left(\mathrm{An}_{40-62}\right)$. Similar compositions of olivine and pyroxene could suggest the presence of xenocrysts or antecryst in the parasitic cones lavas.

\subsubsection{Mount Garet}

Basalts from Mount Garet contain (sub-)euhedral phenocrysts of olivine (Fo $71-80$, clinopyroxene $\left(\mathrm{En}_{39-53}, \mathrm{Wo}_{34-51}, \mathrm{Fs}_{3-18}\right)$, and plagioclase $\left(\mathrm{An}_{63-94}\right.$, with strong reverse zoning) surrounded by a glassy to fine-grained groundmass composed of olivine (Fo53-79), clinopyroxene $\left(\mathrm{En}_{42-49}, \mathrm{Wo}_{42-50}, \mathrm{Fs}_{7-20}\right)$, and plagioclase $\left(\mathrm{An}_{4-13}\right)$. Fe-Ti oxides are hosted in phenocrysts, mainly clinopyroxene. 


\subsection{Major and trace elements}

Volcanic rocks from Gaua range from basalts to andesites and a few dacites exhibiting a wide range of $\mathrm{K}_{2} \mathrm{O}$ compositions, from medium-K calc-alkaline series to (very high-K) shoshonite series (Fig. 4). Such high $\mathrm{K}_{2} \mathrm{O}$ contents, among the highest recorded in the Vanuatu arc (Fig. 4), are restricted to lavas emitted near the DER collision zone (Monzier et al., 1997; Peate et al., 1997). Mount Garet lavas belong exclusively to the medium-K calc-alkaline series, as commonly observed in most Vanuatu islands (Monzier et al., 1997; Peate et al., 1997) and therefore have $\mathrm{K}_{2} \mathrm{O}$ compositions much lower than pre- and syn-caldera lavas (with the exception of sample SM8A). Some basalts (SM2A-SM8A-SM8B-SM52-SM7A) have high L.O.I (> $1 \mathrm{wt} . \%$ ) indicating the presence of post-emplacement alteration. However, no correlation was found between L.O.I and elemental compositions or isotope ratios $(\mathrm{Sr}, \mathrm{Pb})$ sensitive to alteration (not shown).

Major element variations (Fig. 4 and 5) demonstrate that $\mathrm{MgO}, \mathrm{Fe}_{2} \mathrm{O}_{3}, \mathrm{CaO}$ are negatively correlated with silica content, with a slope change between 51 and 52 wt. \% $\mathrm{SiO}_{2}$, whereas $\mathrm{Na}_{2} \mathrm{O}$ and $\mathrm{K}_{2} \mathrm{O}$ display positive correlations $\left(\mathrm{CaO}\right.$ and $\mathrm{Na}_{2} \mathrm{O}$ are not shown). $\mathrm{Al}_{2} \mathrm{O}_{3}$ is positively correlated with silica content for low $\mathrm{SiO}_{2}(<52$ wt. \%) contents and suggests a flat trend for higher $\mathrm{SiO}_{2}$ values. $\mathrm{TiO}_{2}$ does not correlate with $\mathrm{SiO}_{2}$ on Figure 5. A few basalts, belonging to the most mafic samples of the old massif, have relatively high $\mathrm{MgO}$ content reaching 10.6 wt. \%. At a given $\mathrm{SiO}_{2}$ content, the post-caldera lavas are slightly enriched in $\mathrm{Al}_{2} \mathrm{O}_{3}$ (Fig. 5b) and depleted in $\mathrm{P}_{2} \mathrm{O}_{5}$ (not shown) compared to the older ones.

Chondrite-normalized REE patterns (Fig. 6) exhibit moderate to strong enrichment in Light REE (LREE) relative to Heavy REE (HREE), with $(\mathrm{La} / \mathrm{Yb})_{\mathrm{N}}$ ratios ranging between 3 and 9. Pre-caldera lavas display a large range of composition $\left[(\mathrm{La} / \mathrm{Yb})_{\mathrm{N}}\right.$ from 5.7 to 8.8$]$ and give variable REE patterns. Strong similarities are observed between the pyroclastic series and parasitic cone patterns (except for obsidian sample GA21), which all plot in the pre-caldera 
field. Their HREE patterns have a slightly negative to flat slope, except for the two most differentiated samples (dacite GA21 and acidic andesite SM27 labeled on Fig. 6) for which the HREE slope is positive. Some patterns show a negative Eu and/or Ce anomaly (samples labeled SM2A, SM9A and SM8E on Fig. 6) and one sample (labeled SM27 on Figure 6b) show a positive Eu anomaly. Conversely, all the post-caldera lavas display a more limited range of composition with patterns significantly less enriched in $\mathrm{LREE}\left[(\mathrm{La} / \mathrm{Yb})_{\mathrm{N}}\right.$ from 3.3 to 3.7] than the older ones (Fig. 6d).

As commonly observed in arc magmas, the extended trace element patterns (Fig. 7) reveals an enrichment in fluid-mobile LILE elements ( $\mathrm{Rb}, \mathrm{Ba}, \mathrm{K}, \mathrm{Sr}$ ) and (to a lesser extent) in moderately mobile elements (Th, $\mathrm{U}, \mathrm{Pb}$ ), contrasting with a depletion in HFSE such as $\mathrm{Nb}$, Ta, $\mathrm{Zr}$, Hf, and Ti, relative to REE. The enrichment in LILE is among the highest recorded in Vanuatu lavas. Despite some variability among the trace element patterns (Fig. 7), all the Gaua lavas display a single positive trend when two highly incompatible elements such as Th and $\mathrm{Nb}$ are considered (i.e., a constant $\mathrm{Th} / \mathrm{Nb}$ of 1.5 , among the highest of the Vanuatu arc, Fig. 8a). Notably, the $\mathrm{Th} / \mathrm{Nb}$ ratios of lavas from Mount Garet do not differ from older edifices. Conversely, when fluid mobile elements are considered, e.g. Ba vs. La (Fig. 8b), the Gaua lavas show more variable compositions, with $\mathrm{Ba} / \mathrm{La}$ ratios ranging from $~ 26.7$ (old edifice) to $\sim 42.1$ (Mount Garet), with the main cone and syn-caldera lavas displaying intermediate values.

\subsection{Isotopes}

Gaua samples have a restricted isotopic range compared to the whole Vanuatu arc (Fig. 9 and 10), with relatively radiogenic ${ }^{87} \mathrm{Sr} /{ }^{86} \mathrm{Sr}$ ratios from 0.70398 to $0.70420 .{ }^{143} \mathrm{Nd} /{ }^{144} \mathrm{Nd}$ and ${ }^{176} \mathrm{Hf} /{ }^{177} \mathrm{Hf}$ range respectively from 0.51293 to 0.51297 and from 0.28313 to 0.28320 , except sample SM8A from the old edifice, which has the least radiogenic composition (0.51288 and 0.28308, respectively; Fig. 9). The ${ }^{206} \mathrm{~Pb} /{ }^{204} \mathrm{~Pb},{ }^{207} \mathrm{~Pb} /{ }^{204} \mathrm{~Pb}$ and ${ }^{208} \mathrm{~Pb} /{ }^{204} \mathrm{~Pb}$ ratios vary from 
ratios recorded in the Vanuatu arc (Fig. 10). Gaua samples have high ${ }^{87} \mathrm{Sr} /{ }^{86} \mathrm{Sr}$ and low ${ }^{143} \mathrm{Nd} /{ }^{144} \mathrm{Nd}$ and ${ }^{206} \mathrm{~Pb} /{ }^{204} \mathrm{~Pb}$ values, typical of lavas emitted in front of the DER collision zone (e.g. Briqueu et al., 1994; Peate et al., 1997; Laporte et al., 1998). They also fall broadly in the Indian MORB field in $\mathrm{Hf}-\mathrm{Nd}$ and $\mathrm{Pb}-\mathrm{Pb}$ isotopic space (Figs. 9 and 10), but their ${ }^{87} \mathrm{Sr} /{ }^{86} \mathrm{Sr}$ ratios are higher than Indian MORB. Compared to the pre- and syn-caldera lavas, the postcaldera lavas from Mount Garet have higher ${ }^{87} \mathrm{Sr} /{ }^{86} \mathrm{Sr}$ ratios, similar ${ }^{143} \mathrm{Nd} /{ }^{144} \mathrm{Nd}$ ratios (Fig. 9a), and lower ${ }^{206} \mathrm{~Pb} /{ }^{204} \mathrm{~Pb}$ ratios, but similar ${ }^{207} \mathrm{~Pb} /{ }^{204} \mathrm{~Pb}$ and ${ }^{208} \mathrm{~Pb} /{ }^{204} \mathrm{~Pb}$ ratios (Fig. 10).

\section{Discussion}

\subsection{Magmatic differentiation}

\subsubsection{Fractional crystallization}

Major element covariation diagrams (Fig. 5) suggest a three-stage fractional crystallization process. The first stage is characterized by the removal of ferromagnesian minerals (olivine and clinopyroxene), as illustrated by the decrease of $\mathrm{MgO}$ (from ca. 11 to 5 wt. \%) and of $\mathrm{Fe}_{2} \mathrm{O}_{3}$ (from ca. 12.4 to 11 wt. \%) contents (Fig. 5a and c). The inflection shown by the MgO$\mathrm{SiO}_{2}$ trend at ca. 51 wt. $\% \mathrm{SiO}_{2}$ agrees with changes in the slope on the plot of $\mathrm{Al}_{2} \mathrm{O}_{3}$ (and $\mathrm{Sr}$ ) vs. $\mathrm{SiO}_{2}$ and is related to plagioclase fractionation during the second stage (Fig. 5b). This is further supported by the appearance of a slightly negative Eu anomaly on REE patterns of the more evolved lavas (Fig. 6). The high-silica dacites have lower $\mathrm{TiO}_{2}$ content compared to other Gaua samples (0.5 vs. 0.7-0.9 wt. \%) suggesting a greater contribution of Fe-Ti oxides to late stage crystallizing assemblages (Fig. 5d).

Least square modeling of the major element data (Bryan et al., 1969) accounts for one-stage crystallization from the least evolved high-K basalt SM8E to the most evolved high-K dacite GA21 (model \#3, Table 2) with relatively low residual sum of squares $\left(\sum r^{2}=0.23\right)$. This suggests the presence of up to $75 \%$ crystal fractionation for the dacitic composition. Modeling with a three-stage process gives a better fit of the data, especially for the least 
evolved compositions, which is controlled by a decreasing olivine - pyroxene contribution relative to plagioclase $-\mathrm{Fe}$-Ti oxides during crystallization (model \#4, Table 2 , with $\sum \mathrm{r}^{2}=$ $0.04,0.16$ and 0.26 for each stage, respectively). Concerning the post-caldera medium-K series (Mount Garet), modeling successfully accounts for the evolution from the least (SM52) to the most (SM43) evolved lava with $23 \%$ crystallization $\left(\sum r^{2}=0.07\right.$, model 1 , Table 2$)$. However, as previously mentioned, the medium-K magmas cannot evolve to high-K compositions through crystal fractionation (e.g. modeling fails to reproduce the evolution from SM52 to GA21, model 2 with an elevated $\sum r^{2}$ at 1.56, Table 2). In summary, the modeling shows that fractional crystallization processes can explain most of the major element variations of Gaua lavas, and that at least two different magmatic series (medium-K and highK) are required.

\subsubsection{No evidence of Assimilation - Fractional Crystallization}

During ascent through the crust toward the surface, magmas may evolve by concurrent fractional crystallization and crustal assimilation (DePaolo, 1981). This contamination can be tracked by the long-lived radiogenic systems ( $\mathrm{Sr}-\mathrm{Nd}-\mathrm{Pb}-\mathrm{Hf})$ if the contaminant has a distinct isotopic signature. In the case of the Vanuatu island arc, the possible contaminants are: 1) Remnants of old continental crust suspected to have been transported from Australia (Buys et al., 2014), 2) mafic sub-arc crust, as described for Lopevi volcano (Beaumais et al., 2013), and 3) for Mount Garet lavas, pre- or syn-caldera differentiated intrusives (such as the GA21 composition). No correlation between isotopic compositions and $\mathrm{SiO}_{2}$ contents are observed on Figure 11, indicating that if AFC processes occur, it is of limited importance.

\subsection{Mantle source composition}


Although the ${ }^{143} \mathrm{Nd} /{ }^{144} \mathrm{Nd},{ }^{207} \mathrm{~Pb} /{ }^{204} \mathrm{~Pb}$ and ${ }^{208} \mathrm{~Pb} /{ }^{204} \mathrm{~Pb}$ (and to a lesser extent ${ }^{176} \mathrm{Hf} /{ }^{177} \mathrm{Hf}$ ) ratios display a similar range for all Gaua lavas (Figs. 9 and 10), Mount Garet lavas show lower $\mathrm{K}_{2} \mathrm{O}$ and LREE contents (Figs. 4 and 6) and higher ${ }^{87} \mathrm{Sr} /{ }^{86} \mathrm{Sr}$ and lower ${ }^{206} \mathrm{~Pb} /{ }^{204} \mathrm{~Pb}$ ratios than preand syn-caldera lavas (Figs. 12). Such characteristics cannot be ascribed to magmatic differentiation or crustal contamination, and therefore, different mantle sources are required. Basaltic sample SM8A, from the old edifice, has a distinct Nd-Hf isotopic composition compared to all other lavas (Fig. 9), and may require the involvement of an additional distinct mantle source component.

Trace element ratios insensitive to the effect of variations in the degree of partial melting and extent of fractional crystallization, such as $\mathrm{Ce} / \mathrm{Pb}$, vary concomitantly with isotopes in post caldera (Mount Garet), and pre- and syn-caldera basalts ( 3 vs. 5, respectively; Fig. 12b). In summary, these trace element and isotope ratio variations are likely to reflect tapping a heterogeneous mantle source, inherited from the addition of various subduction components to the mantle wedge beneath Gaua. The nature of these component is discussed below.

\subsubsection{Subduction component}

Material transfer from the subducting slab to the overriding plate (McCulloch and Gamble, 1991), is responsible for typical elemental enrichment (such as high $\mathrm{Ba} / \mathrm{La}$ and $\mathrm{La} / \mathrm{Nb}$ )

recorded in arc magmas (Pearce et al., 1995; Elliott, 2003). Differences in the solubility and incompatibility of trace elements in the mobile phase are commonly used to describe the process and evaluate the extent of metasomatism of the mantle wedge.

LILEs (such as $\mathrm{Ba}, \mathrm{Sr}, \mathrm{Pb}$ ) are highly fluid-mobile elements, whereas HFSE, Th, REE are less fluid-mobile elements (Brenan et al., 1995b; Kessel et al., 2005). As a consequence, an imprint from a subduction component dominated by aqueous fluid addition on the arc magmas is characterized by high ratios of more/less fluid-mobile elements (e.g. high $\mathrm{Ba} / \mathrm{Th}$, low $\mathrm{Ce} / \mathrm{Pb})$. The imprint on the arc magmas from a subduction component dominated by addition 
of sediment melts is characterized by high $\mathrm{Th} / \mathrm{REE}$ and $\mathrm{Th} / \mathrm{Nb}$ ratios (Elliott et al., 1997;

Plank, 2005) and high ratios of highly incompatible over less incompatible element, such as La/Sm (Elliott, 2003).

A plot of $\mathrm{La} / \mathrm{Sm}$ vs. Ba/Th ratios (Fig. 13) is often used to constrain the mode of transport (i.e., aqueous fluids and sediment melt) of the subduction component into the mantle source of arc lavas (e.g. Labanieh et al., 2012). Gaua basalts present high Ba/Th (150-300), La/Sm (2.54.5) and $\mathrm{Th} / \mathrm{Nb}(1.5)$ ratios and low $\mathrm{Ce} / \mathrm{Pb}(2-6)$ ratios (Figs. 8a and 13a) compared to $\mathrm{N}$ MORB produced by the melting of the depleted mantle. This implies the involvement of both fluids (high $\mathrm{Ba} / \mathrm{Th}$ and low $\mathrm{Ce} / \mathrm{Pb}$ ) and sediment melts (high $\mathrm{Th} / \mathrm{Nb}$ and $\mathrm{La} / \mathrm{Sm}$ ). Nevertheless, the values of these ratios in the Gaua lavas are relatively low compared to other arcs (Labanieh et al., 2012) and therefore suggest a moderate participation of fluids and melts to the mantle wedge underneath Gaua Island.

\subsubsection{Fluid addition}

Slab dehydration models predict that the content of LILE in aqueous fluids can reach a few hundred ppm (Singer et al., 2007; Ersoy et al., 2010; Tollstrup et al., 2010), whereas the unmetasomatized mantle wedge is typically depleted in incompatible elements (Workman and Hart, 2005). The contribution of $\mathrm{Sr}$ and $\mathrm{Pb}$ from the slab is many times higher than that of the depleted mantle and therefore the isotopic signature of fluid-metasomatized mantle should trend towards those of the subducted plate.

The isotopic signatures of Gaua lavas recorded by fluid-mobile elements ( $\mathrm{Sr}$ and $\mathrm{Pb})$ are significantly distinct between pre- and post-caldera lavas, with a shift towards higher ${ }^{87} \mathrm{Sr} /{ }^{86} \mathrm{Sr}$ and lower ${ }^{206} \mathrm{~Pb} /{ }^{204} \mathrm{~Pb}$ ratios for younger lavas (Fig. 12a). Moreover, post-caldera lavas have lower $\mathrm{Ce} / \mathrm{Pb}$ and higher $\mathrm{Ba} / \mathrm{Th}$ ratios (Figs. 12b and 13a). From these observations we can surmise that mantle sources of pre- and post-caldera lavas were probably metasomatized by at least two distinct slab-derived fluids, with different trace element and isotopic compositions, or were metasomatized to different degrees. 
However, the nature of the fluid source is difficult to constrain because Gaua lavas that exhibit the highest fluid signature (low $\mathrm{Ce} / \mathrm{Pb}$ ) are also the least radiogenic in ${ }^{206} \mathrm{~Pb}$ (Fig. 12b). Known isotopic compositions of the currently subducting plate (DER, NLB) are all more radiogenic in ${ }^{206} \mathrm{~Pb}$ with ${ }^{206} \mathrm{~Pb} /{ }^{204} \mathrm{~Pb}>18.5$ (Fig. 10). This suggests that fluids involved in the Gaua lava mantle source would derive from a low ${ }^{206} \mathrm{~Pb} /{ }^{204} \mathrm{~Pb}$ component, which has not been currently observed in the subducting plate.

\subsubsection{Sediment-melt addition}

The addition of fluids, from the subducting plate, to the mantle wedge can not account for all the geochemical characteristics of the Gaua basalts. The measured isotopic and trace element compositions require the involvement of another metasomatizing agent like sediment melt. Nd and Hf have low mobility in fluids (Brenan et al., 1995a; Kessel et al., 2005), but are efficiently transferred from the sediment to the mantle wedge via sedimentary melting. Consequently, if sediment melts are involved, the isotopic signature of the arc magmas is generally characterized by low $\mathrm{Hf}$ and $\mathrm{Nd}$, high ${ }^{207} \mathrm{~Pb} /{ }^{204} \mathrm{~Pb}$ and $\mathrm{Sr}$ isotopic ratios, reflecting the subducted oceanic sediments (White and Patchett, 1984; Woodhead, 1989; McDermott and Hawkesworth, 1991). Moreover, in intra-oceanic arcs that mainly experience sediment melting, La/Sm and Nd isotopes are negatively correlated (Elliott, 2003; Labanieh et al., 2012). Such a correlation is shown by the Vanuatu basalts (Fig. 13b). Gaua lavas have low Hf and $\mathrm{Nd}$ isotopic ratios similar to the lowest ratios of lavas from the entire Vanuatu arc (Fig. 9), suggesting a relatively large addition of locally subducted sediments into this part of the mantle wedge. However, while the post-caldera Garet basalts fall into the field of the Vanuatu basalts on Figure 13b, the pre- and syn-caldera basalts lie above this field and form a vertical trend towards high $\mathrm{La} / \mathrm{Sm}$ ratios with similar $\mathrm{Nd}$ isotopic ratios.

To investigate the sediment contribution to the Gaua lava mantle source we use a mixing model (Langmuir et al., 1978) between the Depleted Mantle MORB (DMM) and different sediment melts on a La/Sm vs. ${ }^{143} \mathrm{Nd} /{ }^{144} \mathrm{Nd}$ plot (Fig. 13b). The goal of this model is to calculate the composition of the metasomatized mantle source, assuming that rare earth 
elements have low mobility in fluids, we thus ignore this component. Mixing curves are drawn in Figure 13b and input parameters are reported in Table 3. Our model provides several potential metasomatized mantle sources and the composition of their partial melts with higher $\mathrm{La} / \mathrm{Sm}$ ratio but the same $\mathrm{Nd}$ isotopic ratio.

Mixing curves between DMM and sediment melt encompass all basalts from Vanuatu, except the pre- and syn-caldera basalts from Gaua (Fig. 13b). They constrain the sediment melt addition to the sub-arc mantle to less than $2 \%$, consistent with other models performed in other convergent margin settings (e.g. Singer et al., 2007; Tollstrup et al., 2010; Labanieh et al., 2012).

Pre- and syn-caldera basalts lie above the mixing curves, with higher La/Sm but similar ${ }^{143} \mathrm{Nd} /{ }^{144} \mathrm{Nd}$ ratios. This difference can not be explained by the addition of variable amounts of sediment melt to the source. This would likely result from a scenario with different degrees of partial melting of a mantle source with a similar $\mathrm{Nd}$ isotopic composition.

5.3 Mantle partial melting

The effect of variations on the degree of mantle partial melting on Gaua lavas was examined using a non-modal batch melting model (Shaw, 1970): $C_{1}=C_{0} /(D+F(1-P))$, where $C_{1}$ and $\mathrm{C}_{0}$ are the concentration in the magma and in the mantle, respectively; $\mathrm{D}$, the bulk partition coefficient of element (i), with $\mathrm{D}=\Sigma \mathrm{Kd}_{\mathrm{i}} * \mathrm{X}_{\mathrm{i}} ; \mathrm{P}$, the bulk partition coefficient taking into account the proportion of melting $\left(\mathrm{X}_{\mathrm{i}}{ }_{\mathrm{i}}\right)$ of each mineral phases, with $\mathrm{P}=\Sigma \mathrm{Kd}_{\mathrm{i}} * \mathrm{X}_{\mathrm{i}}{ }^{\prime}$; and $\mathrm{F}$, the liquid fraction.

La and Sm were selected for this model because they fractionate during partial melting processes. La and Sm content in the melt is also weakly controlled by the presence of hydrous phases whose Kd between the mineral and melt are very small (e.g. amphibole, phlogopite). Finally, REEs have a relatively low mobility in fluids (Brenan et al., 1995) and are therefore only slightly affected during slab dehydration and mantle metasomatism. We use an estimate 
of the metasomatized mantle source between those calculated by Singer et al. (2007) and

Ersoy et al. (2010), which corresponds to point MM on Figure 14. The parameters used in the model are listed in Table 4.

During partial melting of the mantle wedge, the relative La and Sm contents in the melt are weakly controlled by the presence of Al-rich phases (e.g., garnet or spinel), because their Kd values are very small. For example, the (dashed) garnet- and (solid) spinel-curves from a single mantle source giving comparable slopes on a plot of La/Sm vs. La (Fig. 14). Involvement of hydrous minerals, such as amphibole or mica (sometimes found in metasomatized mantle xenoliths), does not significantly change the slope of the model curves (not shown, using Kd from Adam and Green (2006), mineral assemblage and P from Ersoy et al. (2010)). The main control on the $\mathrm{La} / \mathrm{Sm}$ ratio in mafic lavas is the degree of partial melting. However, for more evolved lavas, this ratio can also be affected by fractional crystallization. Since $\mathrm{Sm}$ is more compatible than La, more evolved rocks show higher La/Sm ratios (Fig. 11c).

Considering the more mafic samples, the model provides a good fit to the Gaua mafic lavas and suggests a lower $(\sim 5 \%)$ and higher $(\sim 10-15 \%)$ degree of partial melting for the precaldera and Mount Garet basalts, respectively. However, values obtained for the oldest lavas are relatively low for an intra-oceanic arc setting, where the degree of partial melting is generally accepted to be between 10 and $30 \%$ (Plank and Langmuir, 1988; Pearce and Parkinson, 1993; Hirose and Kawamoto, 1995).

Thus, different degrees of partial melting of two distinct mantle portions could explain the $\mathrm{La} / \mathrm{Sm}$ difference between the high-K and the medium-K series, as suggested by Peate et al. (1997). These authors invoked a modification of the melting regime by the d'Entrecasteaux Ridge collision to explain the lower degree melts for the high-K lavas, probably generated from a deeper portion of the melting column. In another intra-oceanic arc setting, Stolper and Newman (1994) argued for a relationship between the amount of water in the mantle source and the degree of partial melting responsible for a suite of back-arc lavas from the Mariana trough. A similar geochemical study led by Marske et al. (2011) on Pagan Island (Mariana 
arc), found that Quaternary lavas from two adjacent volcanoes originate from compositionally distinct parental magmas. They proposed that variations in slab contributions (sediments and fluids) to the mantle wedge and the extent of mantle partial melting indicates an addition of fluids. Gaua samples, with the greatest fluid-input signal (high Ba/Th for Garet Mount lavas), also appear to be generated by the highest degree of partial melting. Therefore, elevated fluid contributions to the mantle source of the Mount Garet lavas could be responsible for higher degrees of mantle partial melting.

\subsection{Volcanological implications}

The main cone of Gaua volcano, essentially effusive, consists of a high-K calc-alkaline series. Extensive ash and scoria flow deposits (i.e. Santa Maria Pyroclastic Series), with a dominantly basaltic composition, overlie this edifice which is truncated by a 8.5 x $6 \mathrm{~km}$ caldera. This collapse structure is surrounded by parasitic cones developed along concentric faults and associated lava flows. The active Mount Garet is currently growing inside the caldera, and marks a new cycle of volcanic activity.

The stratigraphic position of the pyroclastic series at the top of the main cone lava pile - cut by the caldera scarp and its spatial distribution around the caldera - points to a relationship between this series and caldera formation (Robin et al., 1995). In volcanic arcs, pyroclastic eruptions involving large volumes of mafic and/or intermediate magmas are scarce. Masaya Volcano in Nicaragua (Williams, 1983), Tanna, Ambrym and Santa María in Vanuatu (Robin et al., 1993, 1995), and Colli Albany Volcano in Italy (De Rita et al., 2002) are among the few volcanoes that have experienced voluminous outbursts of mafic ignimbrites. In Chile, near the end of the last glacial period and during the Holocene, the active volcanoes Villarrica and Llaima experienced large explosive eruptions of mafic to intermediate composition (Lohmar et al., 2007; Lohmar, 2008; Lohmar et al., 2012). At Villarrica volcano, deposits resulting from such events are the Licán Ignimbrite $\left(\sim 10 \mathrm{~km}^{3}\right.$, non-Dense-Rock Equivalent; Lohmar et 
al., 2012) and Pucón Ignimbrite ( $3 \mathrm{~km}^{3}$, non-Dense-Rock Equivalent; Silva Parejas et al., 2010). Compared to these examples, the role of the Santa Maria Pyroclastic Series in the development of Gaua is similar to that of the Lican ignimbrite at Volcan Villarrica. The Vanuatu arc resembles the Ambrym Pyroclastic Sequence but its role in caldera formation differs from the latter. On one hand, the Ambrym Pyroclastic Sequence was probably emplaced over various stages enlargening a few km-wide caldera (i.e. much less wide than the present $12-13 \mathrm{~km}$-wide caldera), which had been previously formed by quiet subsidence. After the Ambrym Pyroclastic Sequence eruption, the resulting structure is a giant tuff cone over a basaltic shield volcano (Robin et al. 1993). At Gaua, similar to Villarrica and Llaima volcanoes, a mafic pyroclastic sequence has an essential (if not unique) role in the formation of the caldera.

Similar major and trace element compositions, $\mathrm{Sr}-\mathrm{Nd}-\mathrm{Pb}-\mathrm{Hf}$ isotopic signatures and mineral assemblages lead us to propose that lavas from the parasitic cones and the Santa Maria Pyroclastic Series are co-genetic (Figs. 4, 6, 7, 9 and 10). The only differences between the centrally and laterally emitted rock series concern their phenocryst content and compositional zoning which are more developed in plagioclase and olivine in the cone series compared to the Santa Maria Pyroclastic Series (not shown). This suggests a longer residence time and magmatic evolution for magmas emitted later at the parasitic cones than for those erupted at the central vent. Both series result from a compositionally layered magma reservoir, where subordinate, differentiated magmas are the result of fractional crystallization from basalts. Compared to the pre- and syn-caldera lavas, Mount Garet basalts show a drastic change in their chemical composition, which seems related to structural modifications of the volcano. In other volcanoes worldwide, post-caldera lavas can be geochemically different (e.g. $\mathrm{SiO}_{2}$ content, Sr isotopes) from the pre- and syn-caldera ones, as a result, for example, of: (1) The modification of the magmatic storage zone (i.e. $\mathrm{P}, \mathrm{T}$ conditions) in the upper part of the crust by caldera collapse [Kos-Nysiros volcanic center, (Bachmann et al., 2012)], (2) various extents of crustal contamination related to the modification of the magmatic plumbing system, from one large single magma chamber to multiple, small, discrete magma chambers (Miyoshi 
et al., 2011), (3) the input of more mafic, co-genetic magmas, such as Krakatau (Gardner et al., 2013) which is thought to have triggered the 1883 caldera-forming eruption (Mandeville et al., 1996) or (4) the input of a more mafic, isotopically distinct magma batch, of deep provenance, such as at Ischia volcano, a suspected trigger of the Monte Epomeo Green Tuff eruptions (Brown et al., 2014). The eruption of all Gaua lavas after the collapse of the caldera until 1962 point to partial melting of another portion of metasomatized mantle. Although the caldera collapse event would not have impacted the sub-arc mantle melting zone, it may have allowed a new batch of magma, stored in a separate magma chamber beneath the volcano and generated by partial melting of another portion of the mantle, to rise to the surface and form Mount Garet. We speculate that the the unloading of the volcanic structure after collapse triggered the ascent and eruption of this new magma batch. The very short time lapse between the eruptions of the two magmatic series suggests that both types of magma were potentially stored within the crust in two separate magma chambers beneath Gaua volcano. Post-caldera lavas sampled at the base of Mount Garet (SM23A, SM25) are more mafic than those (SM42, SM43) sampled at the top (Fig. 3, Table 1), suggesting that the magma evolved at depth.

\section{Conclusions}

This work provides new insights into Gaua volcanism and geological processes affecting the Vanuatu subduction zone.

- Fractional crystallization is the main process controlling the differentiation in both mid-K and high-K series.

- Compared to pre- and syn-caldera basalts, the post caldera lavas of Mount Garet display lower $\mathrm{K}_{2} \mathrm{O}$ content, lower ${ }^{206} \mathrm{~Pb} /{ }^{204} \mathrm{~Pb}$ and $\mathrm{La} / \mathrm{Sm}$ ratios and higher ${ }^{87} \mathrm{Sr} /{ }^{86} \mathrm{Sr}$ and $\mathrm{Ba} / \mathrm{Th}$ ratios, consistent with the tapping of at least two distinct mantle sources beneath Gaua. The existence of an outlier that is less radiogenic in $\mathrm{Nd}$ and $\mathrm{Hf}$ may indicate the minor involvement of a third 
source. This work highlights the compositionally heterogeneous nature of the mantle under the Vanuatu island arc.

- The geochemical differences between the mantle sources are originate from the addition of two distinct slab-derived fluids to the mantle wedge, with slightly distinct $\mathrm{Sr}$ and $\mathrm{Pb}$ isotopic compositions and trace element ratios $(\mathrm{Ba} / \mathrm{Th}, \mathrm{Ce} / \mathrm{Pb})$. Sediment melts $(<2 \%)$ with low ${ }^{143} \mathrm{Nd} /{ }^{144} \mathrm{Nd}$ and relatively high $\mathrm{La} / \mathrm{Sm}$ are also involved.

- Differences in $\mathrm{La} / \mathrm{Sm}$ ratios between the two series, which have the same $\mathrm{Nd}$ isotopic signature, mainly reflect different degrees of partial melting of their respective mantle sources for Mount Garet ( 10-15\%) and for the pre- and syn-caldera basalts $(\sim 5 \%)$.

- The explosive Santa Maria Pyroclastic Series (SMPS) eruption probably triggered the caldera collapse, in response to the emptying of the underlying magma chamber. Late emissions from parasitic cones have identical geochemical composition as that of the SMPS, suggesting that both series are cogenetic. Basalts and andesites from these series likely result from a compositionally layered magma reservoir.

- The collapse of the caldera triggered unprecedented access to the surface from a separate magma chamber holding a geochemically distinct batch of magma beneath the volcano, resulting in the edification of Mount Garet. The two magma chambers are still likely in coexistance beneath Gaua.

\section{Acknowledgments}

We thank the Pole Spectrometry Ocean (Emmanuel Ponzevera, Phillipe Nonotte, Claire Bassoullet, Céline Liorzou), and Shasa Labanieh for their help during the data acquisition. This work was supported by the ANR contract Arc-Vanuatu led by Bernard Pelletier. Nicole Métrich is thanked for the donation of the dacitic sample GA21. We thank Aaron Pietruszka Sylvie Vergniolle and the anonymous reviewer for their very helpful comments and suggestions. Aaron Pietruszka and Jesse Davenport are also thanked for english editing. 


\section{Figure captions}

Figure 1: (a) General map of the south-west Pacific. Black lines represent trenches and arrows indicate the plate movement (b) Map of the Vanuatu islands showing the general tectonic setting adapted from Pelletier et al. (1998) and Calmant et al. (2003). The Vanuatu active arc (central chain) is drawn in dark grey. Western belt (WB) and Eastern belt (EB) are two old inactive arcs. Back Arc Thrust Belt (BATB) is the thrusting of the Eastern belt on the North Fiji Basin (Calmant et al., 2003). Simple arrows indicate the convergence rate in $\mathrm{cm}^{-\mathrm{a}^{-1}}$ of the subducted plate from GPS data (Calmant et al., 2003). Double arrows represent the divergence rates in cm. $\mathrm{a}^{-1}$ in the back arc domain (Price and Kroenke, 1991; Auzende et al., 1994; Huchon et al., 1994; Pelletier et al., 1998). The associated thin lines show the active spreading axes. Grey areas represent ridges and plateaus (submarine relief) on the subducted plate. The dotted line in the north represents the ancient Vitiaz trench lineament. Diamond symbols indicate the location of the DSDP (Deep Sea Drilling Project) hole 286, and ODP (Ocean Drilling Program) Leg 134, holes 828 and 831. Abbreviations: JCT, for Jean Charcot Troughs, CT, for Coriolis Troughs, HHFZ, for Hazel Holmes Fracture Zone and IAB, for Intra-Arc Basin. Open arrows represent the movement of each Vanuatu block ( $\mathrm{N}$ for North, $\mathrm{C}$ for Central and S for South). (c) Bathymetric map of the Banks Islands. Isobaths are drawn every $0.2 \mathrm{~km}$-deep, numbers indicate depth in kilometres.

Figure 2: (a) Geological map of Gaua with the location of samples, adapted from Mallick and Ash (1975) and Robin et al. (1995). (b) Legend: Pre-caldera (1, old edifice; 2, main cone); Syn-caldera (3, pyroclastic series; 4, parasitic cones (small triangles) with associated external lava flows); Post-caldera (5, active Mount Garet volcano).

Figure 3: (a) Topographical map of Mount Garet. Mount Garet topography based on the 
the craters area after an aerial photography made in 1986 (b) Interpretative cross-section XY of Mount Garet volcano, showing its morphology and its geological structure.

Figure 4: $\mathrm{K}_{2} \mathrm{O}$ versus $\mathrm{SiO}_{2}$ diagram (Peccerillo and Taylor, 1976) illustrating the compositional diversity of the Gaua lavas, and the overall dominance of mafic compositions for the Vanuatu lavas (small grey circles: data from Georoc database and from our unpublished data. Legend: (1) this study, (2) data from Robin et al. (1995) and Laporte et al. (1998). Gaua published data are reported in Peate et al. (1997), Turner et al. (1999) and Pearce et al. (2007). Data are presented on a volatile-free basis normalized to $100 \%$.

Figure 5: Major element binary diagrams showing the effect of fractional crystallization with crystallization of olivine and clinopyroxene before plagioclase. (a) $\mathrm{MgO}$, (b) $\mathrm{Al}_{2} \mathrm{O}_{3}$ (inset: $\mathrm{Sr}$ vs. $\mathrm{SiO}_{2}$ ), (c) $\mathrm{Fe}_{2} \mathrm{O}_{3}$ total and (d) $\mathrm{TiO}_{2}$ shown as a function of silica content. Data are presented on a volatile-free basis normalized to $100 \%$.

Figure 6: REE patterns of the Gaua lavas normalized to the chondritic values from McDonough and Sun (1995). Shaded areas correspond to pre-caldera samples. (a) old edifice (b) main cone (c) syn-caldera (d) post-caldera patterns.

Figure 7: Extended trace elements patterns of Lopevi lavas normalized to the N-MORB values from Sun and McDonough (1989). Rare earths are indicated in bold font. Shaded areas correspond to pre-caldera samples and Vanuatu basalts area corresponds to data reported by Peate et al. (1997). (a) old edifice (b) main cone (c) syn-caldera (d) post-caldera patterns.

Figure 8: (a) Th versus $\mathrm{Nb}$ and (b) Ba versus La diagrams showing the behaviour of two highly incompatible elements with similar bulk D values. (a) Gaua lavas display a single ratio $\mathrm{Th} / \mathrm{Nb}$ (1.5). (b) Gaua lavas are heterogeneous and fall between two lines with different $\mathrm{Ba} / \mathrm{La}$ 
ratios defined by the Mount Garet (42.1) and the old edifice (26.7) lavas. Legend: see caption in Figure 4. MORB are from Sun and McDonough (1989)

Figure 9: Isotopic diagrams showing the restricted range of variation of the Gaua lavas. (a) $\mathrm{Nd}-\mathrm{Sr}$ isotope diagram. The mantle array is from Hofmann and White (1982). (b) Hf-Nd isotope diagram. The global correlation is from Graham et al. (2006). The discrimination line is from Pearce et al. (2007). (A) and (B) are the enlargements of (a) and (b) respectively. MORB data are from Meyzen et al. (2007), using the East Pacific Rise data for the Pacific MORB and the South East Indian Ridge data for the Indian MORB (excluding the references from the Australia Antarctica Discordance). Legend: (1) this study, (2) data from Laporte et al. (1998). NLB AOC: Altered Oceanic Crust from the North Loyalty Basin. NLB Sediments: North Loyalty Basin sediments. DER: D'Entrecasteaux Ridge. DER data correspond to samples coming from the ODP Leg134 hole 828 (north) and hole 831 (south). NLB data correspond to samples coming from the DSDP Hole 286 (Fig. 1) and are from Peate et al. (1997), Briqueu et al. (1994) and from Pearce et al. (2007). L for leached samples and UL for unleached samples for Sr isotopic analysis. Vanuatu and Gaua data are from Peate et al. (1997), Laporte et al. (1998), Turner et al. (1999), Pearce et al. (2007), and from personal unpublished data. Among these data, the thick circles correspond to Vanuatu lavas emitted in front to the DER collision zone.

Figure 10: Isotopic diagrams showing the restricted range of variation of the Gaua lavas. (a) ${ }^{208} \mathrm{~Pb} /{ }^{204} \mathrm{~Pb}-{ }^{206} \mathrm{~Pb} /{ }^{204} \mathrm{~Pb}$ and $(\mathrm{b}){ }^{207} \mathrm{~Pb} /{ }^{204} \mathrm{~Pb}-{ }^{206} \mathrm{~Pb} /{ }^{204} \mathrm{~Pb}$ diagrams. The Northern Hemisphere Reference Line is from Hart (1984). The discrimination line is from Kempton et al. (2002). (A) and (B) are the enlargements of (a) and (b) respectively. MORB data are from Meyzen et al. (2007), using the East Pacific Rise data for the Pacific MORB and the South East Indian Ridge data for the Indian MORB (excluding the references from the Australia Antarctica Discordance). Legend: (1) this study, (2) data from Laporte et al. (1998). NLB AOC: Altered Oceanic Crust from the North Loyalty Basin. NLB Sediments: North Loyalty Basin 
sediments. DER: D'Entrecasteaux Ridge. DER data correspond to samples coming from the ODP Leg134 hole 828 (north) and hole 831 (south). NLB data correspond to leached samples coming from the DSDP Hole 286 (Fig. 1) and are from Peate et al. (1997) and Briqueu et al. (1994). Vanuatu data are from Peate et al. (1997), Laporte et al. (1998), Turner et al. (1999), Pearce et al. (2007), and from personal unpublished data.

Figure 11: (a) ${ }^{87} \mathrm{Sr} /{ }^{86} \mathrm{Sr}$ and (b) ${ }^{206} \mathrm{~Pb} /{ }^{204} \mathrm{~Pb}$ ratio (c) $\mathrm{La} / \mathrm{Sm}$ vs. $\mathrm{SiO}_{2}$ diagrams $\left(\mathrm{SiO}_{2}\right.$ as an index of magmatic differentiation). Legend: see caption in Figure 4.

Figure 12: (a) ${ }^{87} \mathrm{Sr} /{ }^{86} \mathrm{Sr}$ and (b) $\mathrm{Ce} / \mathrm{Pb}$ vs. ${ }^{206} \mathrm{~Pb} /{ }^{204} \mathrm{~Pb}$ diagrams, showing the distinct mantle source compositions between post-caldera lavas and older ones. DMM: Depleted MORBMantle. NLB: North Loyalty basin. Legend: see caption in Figure 4.

Figure 13: (a) La/Sm vs. Ba/Th diagram showing the involvement of fluids and sediment melts in the Gaua lava sources. (b) La/Sm vs. ${ }^{143} \mathrm{Nd} /{ }^{144} \mathrm{Nd}$ diagram showing the mixing model described in the text between a Depleted MORB-Mantle (DMM) and various possible sediment melts from the GLOSS (Johnson and Plank, 1999) or from the local North Loyalty basin (NLB) sedimentary unit 1 (U1) (Peate et al., 1997). The mixing proportion are drawn with white circles every $1 \%$ step. Vanuatu basalts are coming from Beaumais et al. (2013) and from unpublished data from the first author. N-MORB composition is from Sun and McDonough (1989). The mean composition (M) of the North Loyalty basin sediments, and also of each sedimentary unit (U1, U2, U3 for unit 1, 2 and 3) are taken from Peate et al. (1997). Sediment melts: JP: Johnson and Plank (1999); K : Kessel et al. (2005) ; HR: Hermann and Rubatto (2009). MK, for medium $\mathrm{K}_{2} \mathrm{O}$, and $\mathrm{HK}$, for high $\mathrm{K}_{2} \mathrm{O}$.

Figure 14: La/Sm vs. La content diagram showing non-modal partial melting models described in the text. DMM: Depleted Mantle MORB (Workman and Hart, 2005). Published calculated metasomatized mantle sources S07 (Singer et al., 2007) and E10 (Ersoy et al., 
2010). MM, for our assumed metasomatized mantle source. Bold lines represent melting models from this metasomatized mantle source. Tick marks drawn on the lines with white circles indicate the partial melting rate $(5,10$ and $15 \%)$.

Table 1: Major elements are presented with total iron as $\mathrm{Fe}_{2} \mathrm{O}_{3}(\mathrm{t})$. Trace elements were measured using the protocol described by Chauvel et al. (2011) on a Thermo Fisher Element 2 (Pôle Spectrometrie Océan, Plouzané). $†$ : Major and trace elements from GA21 sample were analysed in CRPG Nancy. $\mathrm{Sr}$ and $\mathrm{Nd}$ isotopic ratios were measured on a Thermo Fisher Triton, whereas $\mathrm{Pb}$ and $\mathrm{Hf}$ isotopic ratios were analysed on a Thermo Fischer Neptune (PSO, Plouzané). Error on each isotopic measurement is indicated at $\pm 2 \sigma$. Samples ticked with a "L" were leached using concentrated $\mathrm{HBr}$ for $5 \mathrm{~min}$ in an ultrasonic bath prior to dissolution for lead isotopic analysis. We approximate the latitude and longitude of our samples based on the map given by Claude Robin and using the software Google Earth.

Table 2: Fractional crystallization model parameters. This least-squares model is based on 10 oxides, and mineral compositions are from microprobe analyses of phenocrysts. Major element compositions of initial and final melts and the composition of minerals which crystallized are input in the model. The results give the best proportion of minerals removed and the corresponding least squares residuals. In general the residuals should be within the analytical error. $\Delta \mathrm{SiO}_{2}$ is the difference in silica content between the final and the initial composition. $\mathrm{Ol}$, for olivine; $\mathrm{Cpx}$, for clinopyroxene; $\mathrm{Pl}$, for plagioclase; Ox, for $\mathrm{Fe}-\mathrm{Ti}$ oxide. The composition of minerals used is given in supplementary material.

Table 3: Mixing model parameters, including batch melting model parameters for sediment melt composition.

The elemental composition of the DMM comes from Workman and Hart (2005), whereas the Nd isotopic composition of sample D19-1G reported in Fleutelot et al., (2005) is taken as the local depleted mantle. This sample is among the lavas the most radiogenic in $\mathrm{Nd}$ coming from 
the back-arc North Fiji basin, having the least subduction influence with low $\mathrm{Th} / \mathrm{Ta}(<3)$ and $\mathrm{Ba} / \mathrm{Nb}(<7)$, according to the filter described in Woodhead et al. (2012).

The mean composition of the North Loyalty basin subducted sediments has a Nd isotopic signature closed to those of Gaua lavas and cannot be a good end-member. The most superficial sedimentary unit (Unit 1) has the lowest ${ }^{143} \mathrm{Nd} /{ }^{144} \mathrm{Nd}$ ratio and is considered to be the isotopic composition of the sediment-melt end-member. The elemental content of the sediment melt is derived : (1) from calculation from a batch melting models of U1 sediments using the bulk partition coefficients from pelagic red clay sediment melting experiments of Johnson and Plank (1999) performed at $4 \mathrm{GPa}$,and $900^{\circ} \mathrm{C}$ (JP), and from basaltic eclogite melting experiments of Kessel et al., (2005) performed at $6 \mathrm{GPa}$, and $900^{\circ} \mathrm{C}$, as supercritical fluids (K) and (2) from experimental compositions of Hermann and Rubatto (2009) performed on a metapelite melting at $4.5 \mathrm{GPa}$ and $900^{\circ} \mathrm{C}(\mathrm{HR})$. The P-T conditions of experimental work are close to those predicted for the slab roof beneath Gaua $\left(186 \mathrm{~km}\right.$-deep $\left.\sim 5.7 \mathrm{GPa}, 880^{\circ} \mathrm{C}\right)$ by Syracuse et al. (2010). The equation used is from Shaw, 1970: $\mathrm{C}_{\mathrm{SM}}=\mathrm{C}_{\mathrm{sed}} /\left(\mathrm{D}_{\mathrm{sed} / \mathrm{melt}}(1-\right.$ F) + F ). C, D and F are respectively the concentrations of the sediment melt (SM) and sediment (sed), the bulk partition coefficients between sediment and melt, and the degree of partial melting. The F value is fixed at $20 \%$, as proposed for the Vanuatu sediment melting model in Heyworth et al. (2011).

Table 4: Non-modal batch melting model parameters used in melting models. Partition coefficients $\left(\mathrm{Kd}_{\text {mineral/melt }}\right)$ are from Adam and Green (2006) for olivine, orthopyroxene, clinopyroxene and garnet and from Niu and Hekinian (1997) for spinel. The assumed mineral assemblage of the mantle is close to the one used in the partial melting model described by Ersoy et al. (2010) and to peridotite mantle xenoliths sampled in an intra-oceanic arc setting e.g. (Bryant et al., 2007). The Al-rich phase used in the model is either garnet or spinel. The melting mode $\mathrm{P}$ has been taken from Ersoy et al. (2010). A partial melting trend required the composition of our Metasomatized Mantle source (MM) to fit the Gaua data. 


\section{References}

Adam, J. and Green, T., 2006. Trace element partitioning between mica- and amphibolebearing garnet lherzolite and hydrous basanitic melt: 1 . Experimental results and the investigation of controls on partitioning behaviour. Contributions to Mineralogy and Petrology, 152 (1), 1-17.

Auzende, J.M., Pelletier, B. and Eissen, J.P., 1995. The North Fiji Basin: Geology, Structure and geodynamic evolution. In: Taylor, B. (Ed.), Back-arc basin: tectonics and magmatism, New York, pp. 139-175.

Auzende, J.M., Pelletier, B. and Lafoy, Y., 1994. Twin active spreading ridges in the North Fiji Basin (Southwest Pacific). Geology, 22 (1), 63-66.

Bachman, O., Deering, C.D., Ruprecht, J.S., Hubert, C., Skopelitis, A. and Schnyder, C., 2012. Contributions to Mineralogy and Petrology, 163, 151-166.

Bani, P., Boudon, G., Balcone-Boissard, H., Delmelle, P., Quiniou, T., Lefèvre, J., Garaebiti Bule, E., Hiroshi, S. and Lardy, M., 2015. The 2009-2010 euption of Gaua volcano (Vanuatu archipelogo): Eruptive dynamics and unsuspected strong halogens source. Journal of Volcanology and Geothermal Research, this volume.

Barrat, J.A., Zanda, B., Moynier, F., Bollinger, C., Liorzou, C. and Bayon, G., 2012. Geochemistry of CI chondrites: Major and trace elements, and $\mathrm{Cu}$ and $\mathrm{Zn}$ Isotopes. Geochimica Et Cosmochimica Acta, 83, 79-92.

Beaumais, A., Chazot, G., Dosso, L. and Bertrand, H., 2013. Temporal source evolution and crustal contamination at Lopevi Volcano, Vanuatu Island Arc. Journal of Volcanology and Geothermal Research, 263, 72-84.

Brenan, J.M., Shaw, H.F. and Ryerson, F.J., 1995a. Experimental-evidence for the origin of lead enrichment in convergent-margin magmas. Nature, 378 (6552), 54-56.

Brenan, J.M., Shaw, H.F., Ryerson, F.J. and Phinney, D.L., 1995b. Mineral-aqueous fluid partitioning of trace-elements at 900 degrees-C and 2.0 gpa - Constraints on the traceelement chemistry of mantle and deep-crustal fluids. Geochimica et Cosmochimica Acta, 59 (16), 3331-3350.

Briqueu, L. and Lancelot, J.R., 1983. Sr isotopes and K, Rb, Sr balance in sediments and igneous rocks from the subducted plate of the Vanuatu (New Hebrides) active margin. Geochimica et Cosmochimica Acta, 47, 191-200.

Briqueu, L., Laporte, C., Crawford, A.J., Hasenaka, T., Baker, P.E. and Coltorti, M., 1994. Temporal magmatic evolution of the Aoba Basin, central New Hebrides island arc; $\mathrm{Pb}$, $\mathrm{Sr}$, and $\mathrm{Nd}$ isotopic evidence for the coexistence of two mantle components beneath the arc. In: Greene, H.G., Collot, J.Y., Stokking, L.B. et al. (Eds.), Proceedings of the 
Ocean Drilling Program, Scientific Results, 134, College Station, TX, United States (USA), pp. 393-401.

Brown, R.J., Civetta, L., Arienzo, I., D’Antonio, M., Moretti, R., Orsi, G., Tomlinson, E. L., Albert, P.G. and Menzies M. A., 2014. Geochemical and isotopic insights into the assembly, evolution and disruption of a magmatic plumbing system before and after a cataclysmic caldera-collapse eruption at Ischia volcano (Italy). Contributions to Mineralogy and Petrology, 168 (3), 1035.

Bryan, W.B., Finger, L.W. and Chayes, F., 1969. Estimating proportions in petrographic mixing equations by least-squares approximation. Science, 163 (3870), 926-927.

Bryan, W.B., Finger, L.W. and Chayes, F., 1969. Estimating proportions in petrographic mixing equations by least-squares approximation. Science, 163 (3870), 926-927.

Bryant, J.A., Yogodzinski, G.M. and Churikova, T.G., 2007. Melt-mantle interactions beneath the Kamchatka arc: Evidence from ultramafic xenoliths from Shiveluch volcano. Geochemistry Geophysics Geosystems, 8 (4).

Buys, J., Spandler, C., Holm, R. J., Richards, W., 2014. Remnants of ancient Australia in Vanuatu: Implications for crustal evolution in island arcs and tectonic development of the southwest Pacific. Geology, 42 (11), 939-942.

Calanchi, N., Peccerillo, A., Tranne, C.A., Lucchini, F., Rossi, P.L., Kempton, P.D., Barbieri, M. and Wu, T.W., 2002. Petrology and geochemistry of volcanic rocks from the island of Panarea: implications for mantle evolution beneath the Aeolian island arc (southern Tyrrhenian Sea). Journal of Volcanology and Geothermal Research, 115, 367-395.

Calmant, S., Pelletier, B., Lebellegard, P., Bevis, M., Taylor, F.W. and Phillips, D.A., 2003. New insights on the tectonics along the New Hebrides subduction zone based on GPS results. Journal of Geophysical Research-Solid Earth, 108 (B6), 2319-2340.

Chauvel, C., Bureau, S. and Poggi, C., 2011. Comprehensive chemical and isotopic analyses of basalt and sediment reference materials. Geostandards and Geoanalytical Research, 35 (1), 125-143.

DePaolo, D.J., 1981. Trace-element and isotopic effects of combined wallrock assimilation and fractional crystallization. Earth and Planetary Science Letters, 53 (2), 189-202.

DeRita, D., Giordano, G. Esposito, A., Fabbri, M., Rodano, S., 2002. Large volume phreatomagmatic ignimbrites from the Colli Albani volcano (middle Pleistocene, Italy). Journal of Volcanology and Geothermal Research, 118, 77-98.

Dickinson, W.R., 1970. Relations of andesites, granites, and derivative sanstones to arctrench tectonics. Review of Geophysics and Space Physics 8(4), 813-861.

Edwards, C.M.H., Menzies, M.A., Thirlwall, M.F., Morris, J., Leeman, W.P. and Harmon, R.S., 1994. The Transition to Potassic Alkaline Volcanism in Island Arcs: The Ringgit-Beser Complex, East Java, Indonesia. Journal of Petrology, 35 (6), 1557-1595. 
Elliott, T., 2003. Tracers of the slab. In: Eiler, J. (Ed.), Inside the subduction factory. Geophysical Monograph, American Geophysical Union, pp. 23-45.

Elliott, T., Plank, T., Zindler, A., White, W. and Bourdon, B., 1997. Element transport from slab to volcanic front at the Mariana arc. Journal of Geophysical Research-Solid Earth, 102 (B7), 14991-15019.

Ersoy, E.Y., Helvaci, C. and Palmer, M.R., 2010. Mantle source characteristics and melting models for the early-middle Miocene mafic volcanism in Western Anatolia: Implications for enrichment processes of mantle lithosphere and origin of K-rich volcanism in post-collisional settings. Journal of Volcanology and Geothermal Research, 198, 112-128.

Fleutelot, C., Eissen, J.P., Dosso, L., Juteau, T., Launeau, P., Bollinger, C., Cotten, J., Danyushevsky, L. and Savoyant, L., 2005. Petrogenetic variability along the NorthSouth Propagating Spreading Center of the North Fiji Basin. Mineralogy and Petrology, 83 (1-2), 55-86.

Francalanci, L., Manetti, P. and Peccerillo, A., 1989. Volcanological and magmatological evolution of Stromboli volcano (Aeolian Islands): the roles of fractional crystallization, magma mixing, crustal contamination and source heterogeneity. Bulletin of Volcanology, 51, 355-378.

Francalanci, L., Braschi, E., Di Salvo, S., Lucchi, F., Petrone, C.M., 2014. When magmas do not interact: paired Roman-age activity revealed by tephra studies at Stromboli volcano. Bulletin of Volcanology, 76, 884-901.

Galer, S.J.G. and Abouchami, W., 1998. Practical application of lead triple spiking for correction of instrumental mass discrimination, Goldschmidt conference, Toulouse.

Gardner, M.F., Troll, V.R., Gamble, J.A., Gertisser, R., Hart, G.L., Ellam, R.M., Harris, C. and Wolff, J.A., 2013. Crustal differentiation processes at Krakatau volcano, Indonesia. Journal of Petrology, 54 (1), 149-182.

Gertisser, R. and Keller, J., 2003. Trace element and Sr, Nd, pb, and O isotope variations in medium-K and high-K volcanic rocks from Merapi volcano, Central Java, Indonesia: Evidence for the involvement of subducted sediments in Sunda Arc magma genesis. Journal of Petrology, 44 (3), 457-489.

Graham, D.W., Blichert-Toft, J., Russo, C.J., Rubin, K.H. and Albarède, F., 2006. Cryptic striations in the upper mantle revealed by hafnium isotopes in southeast Indian ridge basalts. Nature, 440 (7081), 199-202.

Hart, S.R., 1984. A large-scale isotope anomaly in the Southern-Hemisphere mantle. Nature, 309 (5971), 753-757.

Hermann, J. and Rubatto, D., 2009. Accessory phase control on the trace element signature of sediment melts in subduction zones. Chemical Geology, 265(3-4), 512-526. 
Hermann, J. and Spandler, C.J., 2008. Sediment melts at sub-arc depths: An experimental study. Journal of Petrology, 49 (4), 717-740.

Heyworth, Z., Knesel, K.M., Turner, S.P. and Arculus, R.J., 2011. Pb-isotopic evidence for rapid trench-parallel mantle flow beneath Vanuatu. Journal of the Geological Society, 168 (1): 265-271.

Hirose, K. and Kawamoto, T., 1995. Hydrous partial melting of lherzolite at $1 \mathrm{GPa}-$ The effect of $\mathrm{H} 2 \mathrm{O}$ on the genesis of basaltic magmas. Earth and Planetary Science Letters, 133 (3-4), 463-473.

Hofmann, A.W. and White, W.M., 1982. Mantle plume from ancient oceanic-crust. Earth and Planetary Science Letters, 57 (2), 421-436.

Huchon, P., Gracia, E., Ruellan, E., Joshima, M. and Auzende, J.M., 1994. Kinematics of active spreading in the central North Fiji Basin (Southwest Pacific). Marine Geology, $116(1-2), 69-87$.

Jochum, K.P. and Brueckner, S.M., 2008. Reference Materials in Geoanalytical and Environmental Research - Review for 2006 and 2007. Geostandards and Geoanalytical Research, 32 (4), 405-452.

Johnson, M.C. and Plank, T., 1999. Dehydration and melting experiments constrain the fate of subducted sediments. Geochemistry Geophysics Geosystems, 1.

Kempton, P.D., Pearce, J.A., Barry, T.L., Fitton, J.G., Langmuir, C. and Christie, D.M., 2002. $\mathrm{Sr}-\mathrm{Nd}-\mathrm{Pb}-\mathrm{Hf}$ isotope results from ODP Leg 187: Evidence for mantle dynamics of the Australian-Antarctic Discordance and origin of the Indian MORB source. Geochemistry Geophysics Geosystems, 3.

Kessel, R., Schmidt, M.W., Ulmer, P. and Pettke, T., 2005. Trace element signature of subduction-zone fluids, melts and supercritical liquids at 120-180 km depth. Nature, 437 (7059), 724-727.

Labanieh, S., Chauvel, C., Germa, A. and Quidelleur, X., 2012. Martinique: a Clear Case for Sediment Melting and Slab Dehydration as a Function of Distance to theTrench. Journal of Petrology, 53 (12), 2441-2464.

Langmuir, C.H., Vocke, R.D., Hanson, G.N. and Hart, S.R., 1978. A general mixing equation with applications to icelandic basalts. Earth and Planetary Science Letters, 37, 380392.

Laporte, C., Briqueu, L., Cluzel, D. and Eissen, J.P., 1998. Isotopic gradient along the New Hebrides arc (Vanuatu, SW Pacific). Collision of the d'Entrecasteaux Zone and heterogeneity of mantle sources. Comptes Rendus de l'Académie des Sciences II Fascicule A - Science de la Terre et des Planètes, 326 (2), 101-106.

Lohmar, S., 2008. Petrología de las ignimbritas Licán y Pucón (Volcán Villarrica) y Curacautín (Volcán Llaima) en los Andes del Sur de Chile. PhD Thesis, Université 
Blaise Pascal (France) — Universidad de Chile, Santiago, Chile.

Lohmar, S., Robin, C., Gourgaud, A., Clavero, J., Parada, M.A., Moreno, H., Ersoy, O., López-Escobar, L., Naranjo, J.A., 2007. Evidence of magma-water interaction during the 13,800 years BP explosive cycle of the Licán ignimbrite, Villarrica volcano (Southern Chile). Revista Geológica de Chile 34 (2), 233-247.

Lohmar S., Parada M-A., Gutiérrez F., Robin C., Gerbe M-C., 2012. Mineralogical and numerical approaches to establish the pre-eruptive conditions of the mafic Licán Ignimbrite, Villarrica Volcano (Chilean Southern Andes). Journal of Volcanology and Geothermal Research 235, 55-69.

MacFarlane, A., Carney, J.N., Crawford, A.J. and Greene, H.G., 1988. Vanuatu - A review of the onshore geology. In: Greene, H.G.W.F.L. (Ed.), Geology and offshore resources of Pacific Island Arcs - Vanuatu region. Earth Science Series. Circum-Pacific Council for Energy and Mineral Resources, Houston, TX, United States (USA), pp. 24-68.

Mallick, D.I.J. and Ash, R.P., 1975. Geology of the Southern Banks Islands. British Service, New Hebrides, Port Vila, 33 pp.

Mandeville, C.W., Carey, S, and Sigurdsson, H., 1996. Magma mixing, fractional crystallization and volatile degassing during the 1883 eruption of krakatau volcano, Indonesia. Journal of Volcanology and Geothermal Research, 74, 243-274.

Manhès, G., Allègre, C.J. and Provost, A., 1984. U-Th-Pb systematics of the eucrite juvinas Precise age-determination and evidence for exotic lead. Geochimica et Cosmochimica Acta, 48 (11), 2247-2264.

Marske, J.P., Pietruszka, A.J., Trusdell, F.A. and Garcia, M.O., 2011. Geochemistry of southern Pagan Island lavas, Mariana arc: the role of subduction zone processes. Contributions to Mineral Petrology, 162, 231-252.

McCulloch, M.T. and Gamble, J.A., 1991. Geochemical and geodynamical constraints on subduction zone magmatism. Earth and Planetary Science Letters, 102 (3-4), 358-374.

McDermott, F. and Hawkesworth, C., 1991. Th, Pb, and Sr isotope variations in young islandarc volcanics and oceanic sediments. Earth and Planetary Science Letters, 104 (1), 115.

McDonough, W.F. and Sun, S.S., 1995. The composition of the Earth. Chemical Geology, 120 (3-4), 223-253.

Miyoshi, M., Shibata, T., Yoshikawa, M., Sano, T., Shinmura, T. and Hasenaka, T., 2011. Genetic relationship between post-caldera and caldera-forming magmas from Aso volcano, SW Japan: Constraints from Sr isotope and trace element compositions. Journal of Mineralogical and Petrological Sciences, 106, 114-119.

Meffre, S. and Crawford, A.J., 2001. Collision tectonics in the New Hebrides arc (Vanuatu). Island Arc, 10 (1), 33-50. 
Métrich, N., Bertagnini, A., Garaebiti, Vergniolle, S., Bani, P., Beaumais, A. and Neuville, D.R., 2015. Magma transfert and degassing budget during the 2009-2010 eruptive crisis of Mount Garet (Vanuatu arc). Journal of Volcanology and Geothermal Research, this volume.

Meyzen, C.M., Blichert-Toft, J., Ludden, J.N., Humler, E., Mevel, C. and Albarède, F., 2007. Isotopic portrayal of the Earth's upper mantle flow field. Nature, 447 (7148), 10691074.

Monjaret, M.C., 1989. Le magmatisme des fossés à l'arrière de l'arc des Nouvelles Hebrides (Vanuatu), Université de Bretagne Occidentale, Brest, 500 pp.

Monzier, M., Robin, C., Eissen, J.P. and Cotten, J., 1997. Geochemistry vs. seismo-tectonics along the volcanic New Hebrides Central Chain (Southwest Pacific). Journal of Volcanology and Geothermal Research, 78 (1-2), 1-29.

Nichols, G.T., Wyllie, P.J. and Stern, C.R., 1994. Subduction zone-melting of pelagic sediments constrained by melting experiments. Nature, 371 (6500), 785-788.

Niu, Y.L. and Hekinian, R., 1997. Basaltic liquids and harzburgitic residues in the Garrett Transform: A case study at fast-spreading ridges. Earth and Planetary Science Letters, 146 (1-2), 243-258.

Pearce, J.A., Baker, P.E., Harvey, P.K. and Luff, I.W., 1995. Geochemical evidence for subduction fluxes, mantle melting and fractional crystallization beneath the South Sandwich-island arc. Journal of Petrology, 36 (4), 1073-1109.

Pearce, J.A., Kempton, P.D. and Gill, J.B., 2007. Hf-Nd evidence for the origin and distribution of mantle domains in the SW Pacific. Earth and Planetary Science Letters, 260 (1-2), p 98-114.

Pearce, J.A. and Parkinson, I.J., 1993. Trace element models for mantle melting: application to volcanic arc petrogenesis. Geological Society, London, Special Publications, 76, 373-403.

Peate, D.W., Pearce, J.A., Hawkesworth, C.J., Colley, H., Edwards, C.M.H. and Hirose, K., 1997. Geochemical variations in Vanuatu arc lavas: the role of subducted material and a variable mantle wedge composition. Journal of Petrology, 38 (10), 1331-1358.

Pelletier, B., Calmant, S. and Pillet, R., 1998. Current tectonics of the Tonga New Hebrides region. Earth and Planetary Science Letters, 164 (1-2), 263-276.

Plank, T., 2005. Constraints from thorium/lanthanum on sediment recycling at subduction zones and the evolution of the continents. Journal of Petrology, 46 (5), 921-944.

Plank, T. and Langmuir, C.H., 1988. An evaluation of the global variations in the major element chemistry of arc basalts. Earth and Planetary Science Letters, 90 (4), 349-370.

Plank, T. and Langmuir, C.H., 1998. The chemical composition of subducting sediment and its consequences for the crust and mantle. Chemical Geology, 145 (3-4), 325-394. 
Pontoise, B., Charvis, P. and Gérard, M., 1994. Sedimentary and crustal structure of the north Aoba Basin from seismic refraction data. In: Greene, H.G., Collot, J.Y., Stokking, L.B. et al. (Eds.), Proceedings of the Ocean Drilling Program, Scientific Results, 134, College Station, TX, United States (USA), pp. 549-563.

Price, R.C. and Kroenke, L.W., 1991. Tectonics and magma genesis in the northern North Fiji Basin. Marine Geology, 98 (2-4), 241-258.

Richard, P., Shimizu, N. and Allègre, C.J., 1976. Nd143/Nd146 A natural tracer - Application to oceanic basalt. Earth and Planetary Science Letters, 31 (2), 269-278.

Robin, C., Eissen, J.P., Monzier, M., 1993. Giant tuff cone and 12 km-wide associated caldera at Ambrym (New Hebrides Arc). Journal of Volcanology and Geothermal Research, $55,225-238$.

Robin, C., Eissen, J.P. and Monzier, M., 1995. Mafic pyroclastic flows at Santa-Maria (Gaua) volcano, Vanuatu - the caldera formation problem in mainly mafic island-arc volcanos. Terra Nova, 7 (4), 436-443.

Shaw, D.M., 1970. Trace element fractionation during anatexis. Geochimica et Cosmochimica Acta, 34 (2), 237-243.

Singer, B.S., Jicha, B.R., Leeman, W.P., Rogers, N.W., Thirlwall, M.F., Ryan, J. and Nicolaysen, K.E., 2007. Along-strike trace element and isotopic variation in Aleutian Island arc basalt: Subduction melts sediments and dehydrates serpentine. Journal of Geophysical Research-Solid Earth, 112 (B6).

Sun, S.S. and McDonough, W.F., 1989. Chemical and isotopic systematics of oceanic basalts: Implications for mantle composition and processes, Chemical and isotopic systematics of oceanic basalts. Geological Society, London, Special Publications, pp. 313-345.

Silva Parejas, C., Druitt, T. H., Robin, C., Moreno, H., Naranjo, J.-A., 2010. The Holocene Pucón eruption of Volcán Villarrica, Chile: deposit architecture and eruption chronology. Bulletin of Volcanology, 72 (6), 677-692.

Stolper, E. and Newman, S., 1994. The role of water in the petrogenesis of Mariana trough magmas. Earth and Planetary Science Letters, 121 (3-4), 293-325.Syracuse, E.M. and Abers, G.A., 2006. Global compilation of variations in slab depth beneath arc volcanoes and implications. Geochemistry Geophysics Geosystems, 7.

Syracuse, E.M., van Keken, P.E. and Abers, G.A., 2010. The global range of subduction zone thermal models. Physics of the Earth and Planetary Interiors, 183 (1-2), 73-90.

Taylor, F.W., 1992. The d'Entrecasteaux Zone - New Hebrides Island arc collision zone: an overview. In: Greene, H.G., Collot, J.Y., Stokking, L.B. et al. (Eds.), Proceedings of the Ocean Drilling Program, Initial Reports, 134, College Station, TX, United States (USA), pp. 19-31. 
Tollstrup, D., Gill, J., Kent, A., Prinkey, D., Williams, R., Tamura, Y. and Ishizuka, O., 2010. Across-arc geochemical trends in the Izu-Bonin arc: Contributions from the subducting slab, revisited. Geochemistry Geophysics Geosystems, 11.

Turner, S.P., Peate, D.W., Hawkesworth, C.J., Eggins, S.M. and Crawford, A.J., 1999. Two mantle domains and the time scales of fluid transfer beneath the Vanuatu arc. Geology, 27 (11), 963-966.

White, W.M., Albarède, F. and Telouk, P., 2000. High-precision analysis of Pb isotope ratios by multi-collector ICP-MS. Chemical Geology, 167(3-4), 257-270.

White, W.M. and Patchett, J., 1984. Hf-Nd-Sr isotopes and incompatible element abundances in island arcs: implications for magmas origins and crust-mantle evolution. Earth and Planetary Science Letters, 67, 167-185.

Wilson, M. (Editor), 1989. Igneous Petrogenesis: a global tectonic approach.

Williams, S., 1983. Geology and eruptive mechanisms of Masaya caldera complex, Nicaragua. Ph.D. Thesis, Dartmouth College Hanover, New Hampshire, USA.

Woodhead, J., Stern, R.J., Pearce, J., Hergt, J. and Vervoort, J., 2012. Hf-Nd isotope variation in Mariana Trough basalts: The importance of "ambient mantle" in the interpretation of subduction zone magmas. Geology, 40 (6), 539-542.

Woodhead, J.D., 1989. Geochemistry of the mariana arc (Western Pacific) - Source composition and processes. Chemical Geology, 76 (1-2), 1-24.

Workman, R.K. and Hart, S.R., 2005. Major and trace element composition of the depleted MORB mantle (DMM). Earth and Planetary Science Letters, 231 (1-2), 53-72.

Yang, Y.H., Zhang, H.F., Chu, Z.Y., Xie, L.W. and Wu, F.Y., 2010. Combined chemical separation of $\mathrm{Lu}, \mathrm{Hf}, \mathrm{Rb}, \mathrm{Sr}, \mathrm{Sm}$ and $\mathrm{Nd}$ from a single rock digest and precise and accurate isotope determinations of $\mathrm{Lu}-\mathrm{Hf}, \mathrm{Rb}-\mathrm{Sr}$ and $\mathrm{Sm}-\mathrm{Nd}$ isotope systems using Multi-Collector ICP-MS and TIMS. International Journal of Mass Spectrometry, 290 (2-3), 120-126. 


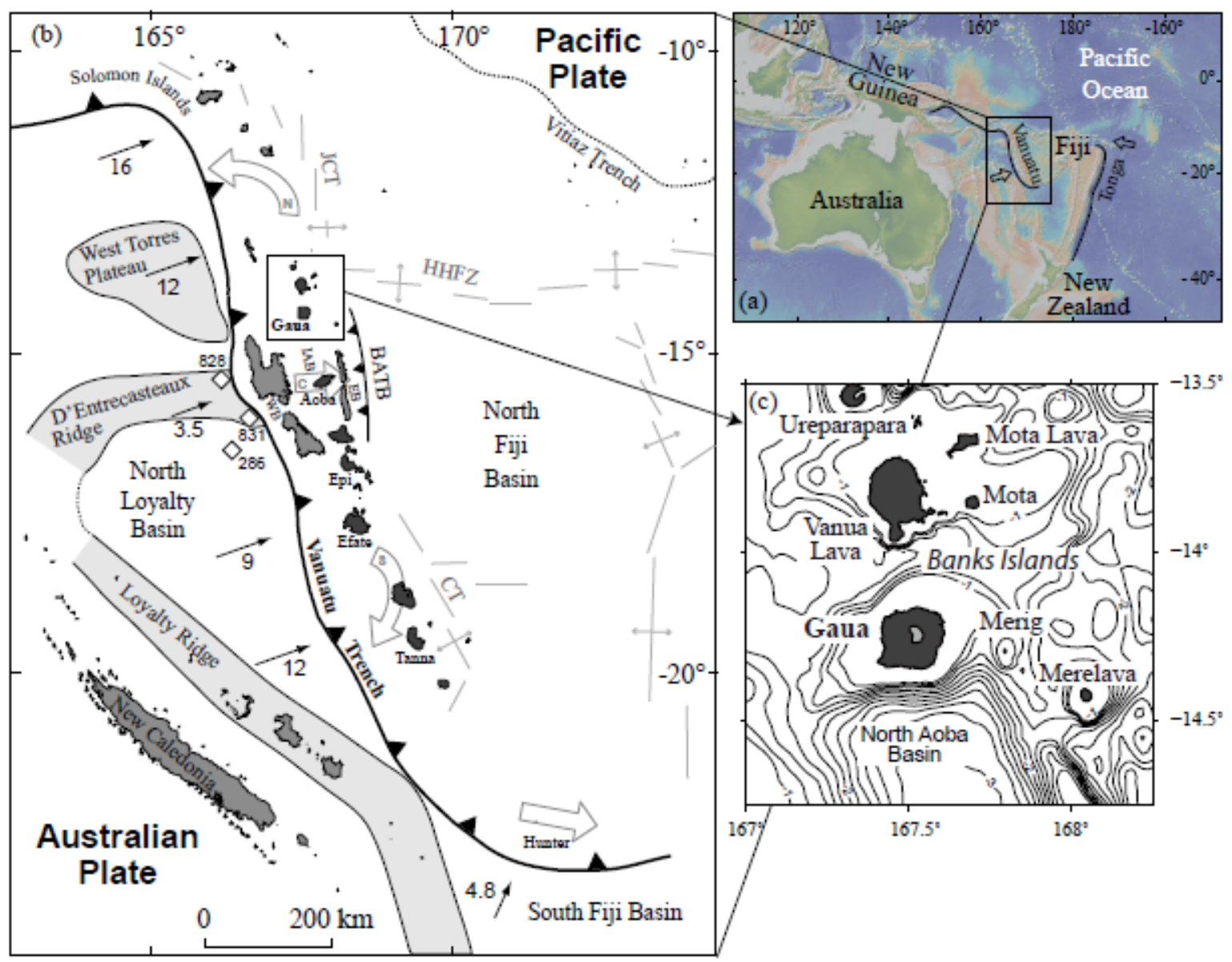

Figure 1 


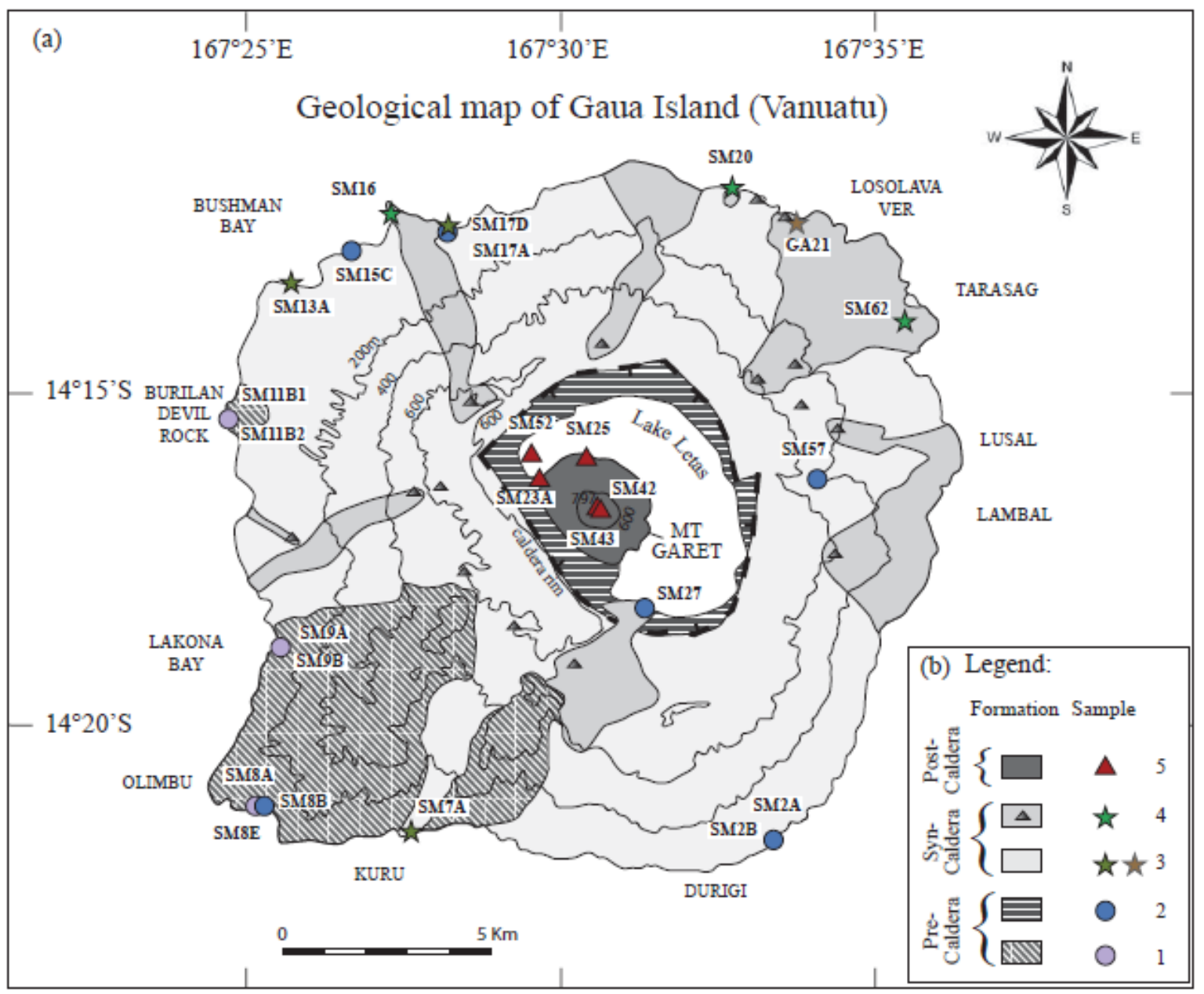

Figure 2 


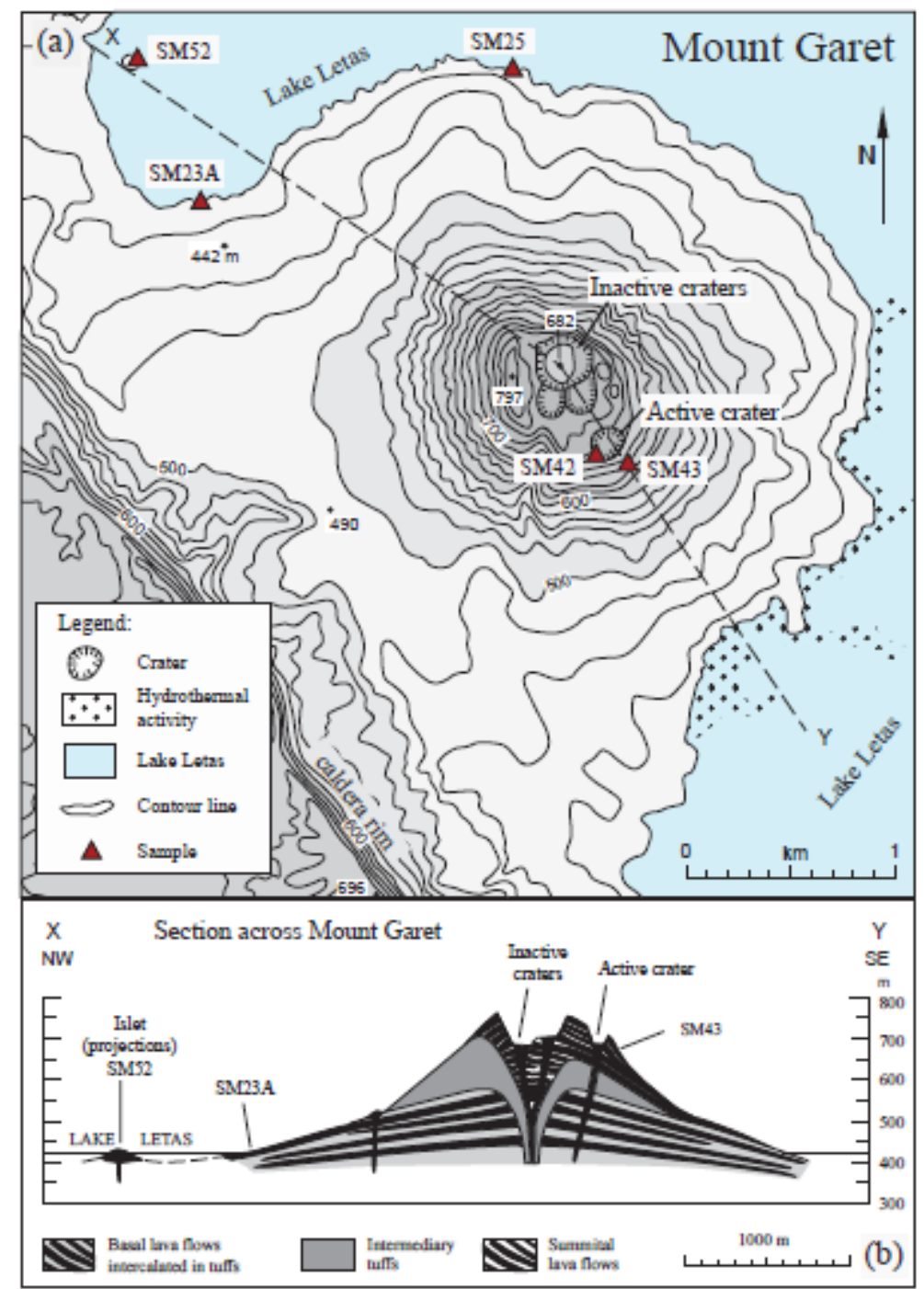

Figure 3 


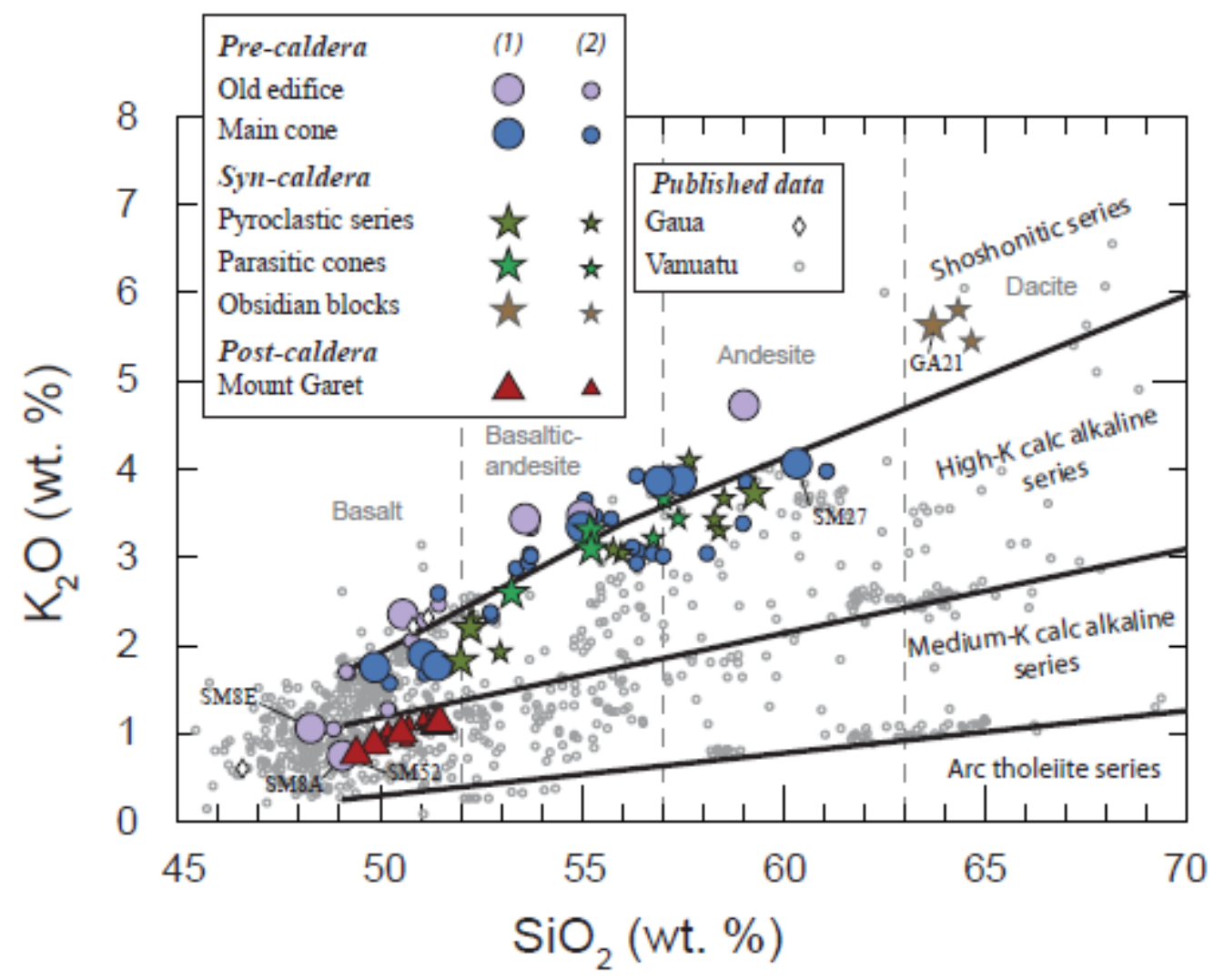

Figure 4 


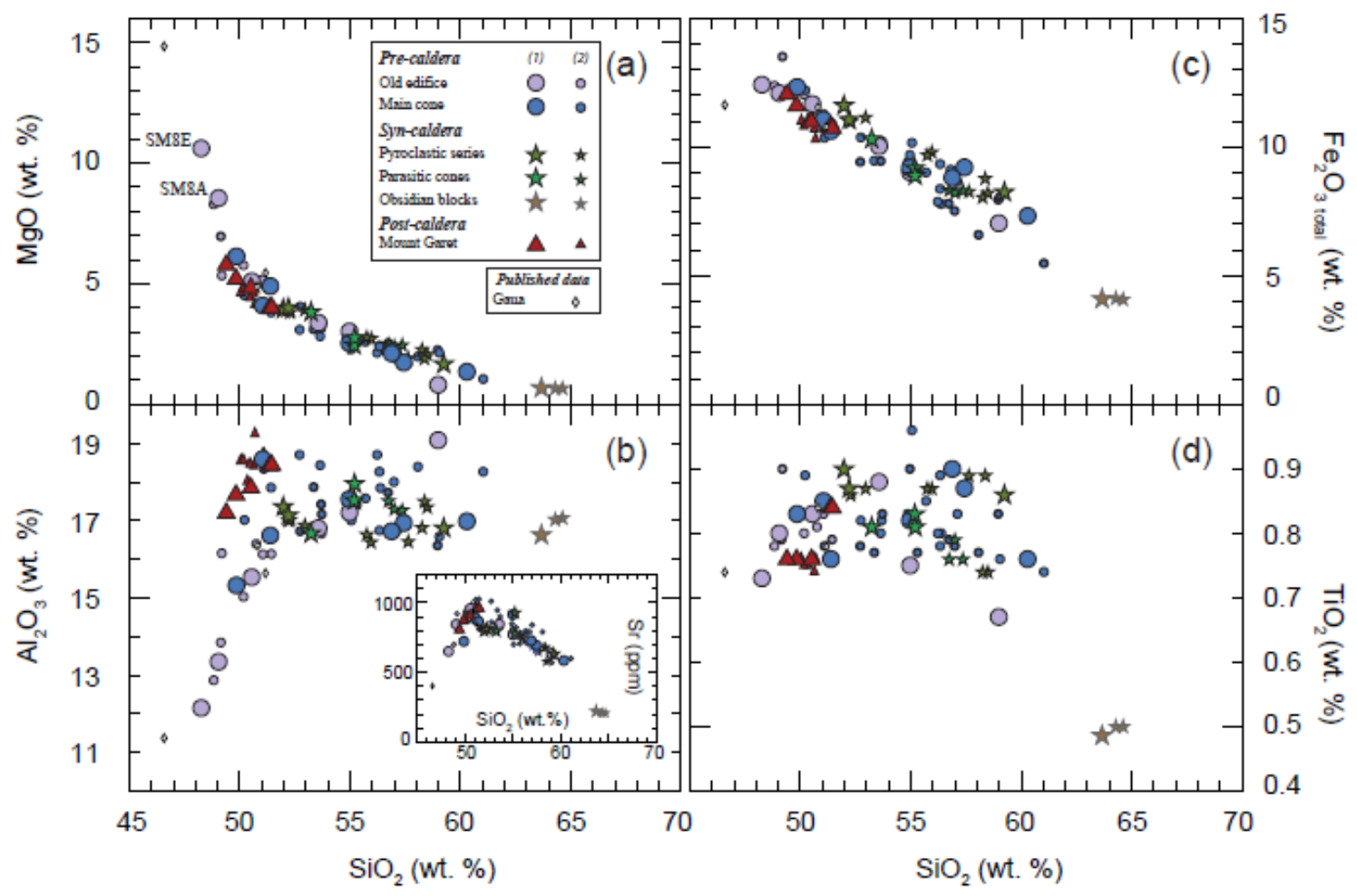

Figure 5 

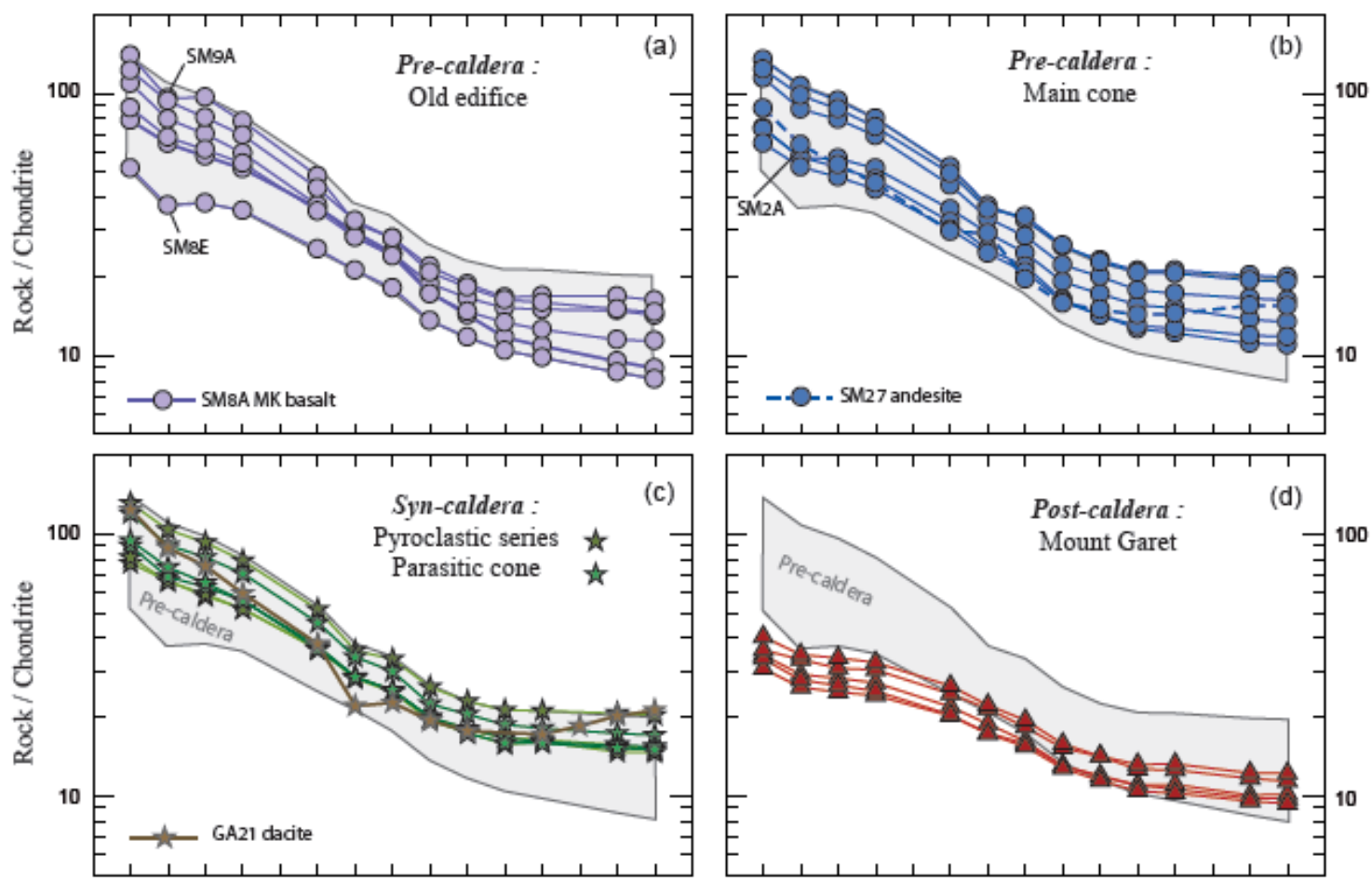

La Ce Pr Nd Pm Sm Eu Gd Tb Dy Ho Er Tm Yb Lu

La Ce Pr Nd Pm Sm Eu Gd Tb Dy Ho Er Tm rb Lu

Figure 6 


$$
M=M=
$$



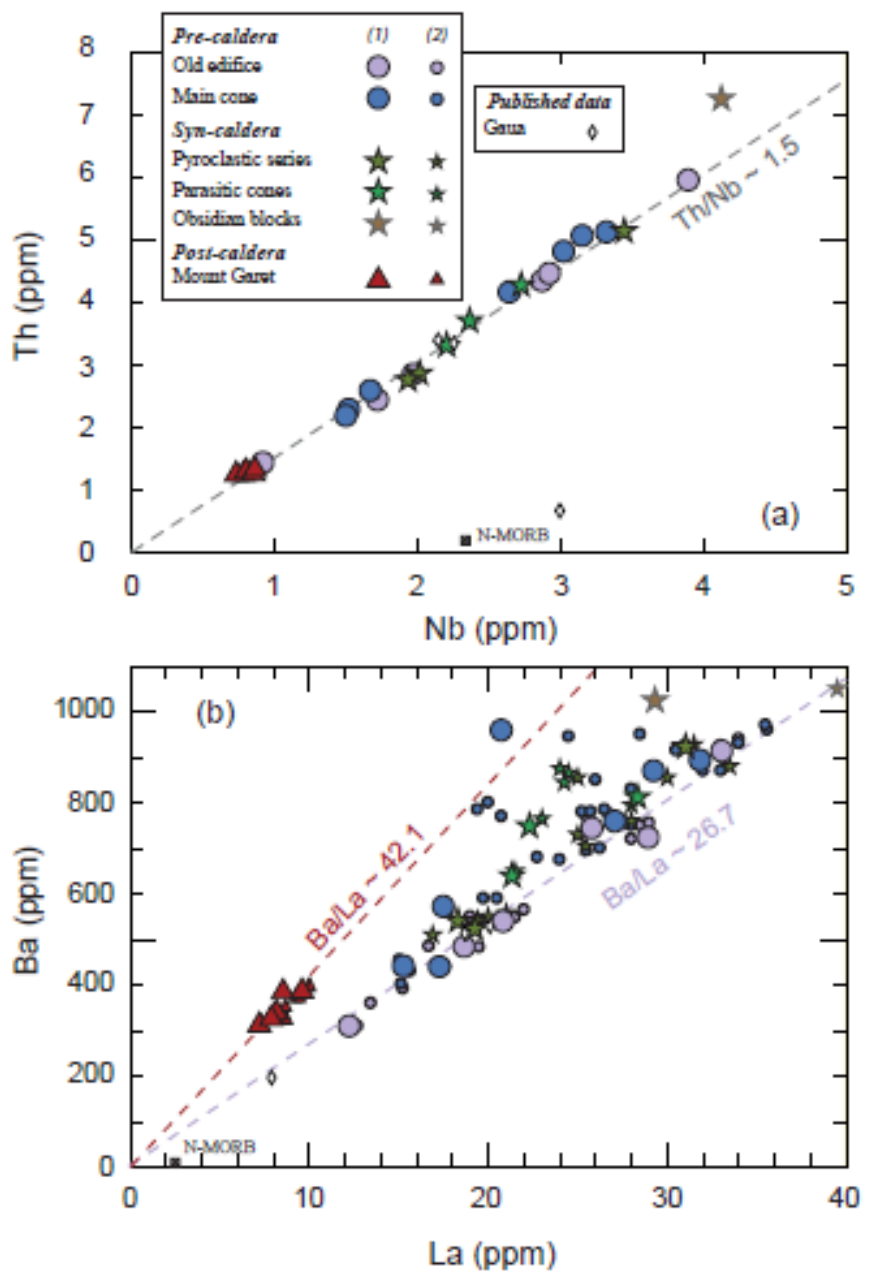

Figure 8 

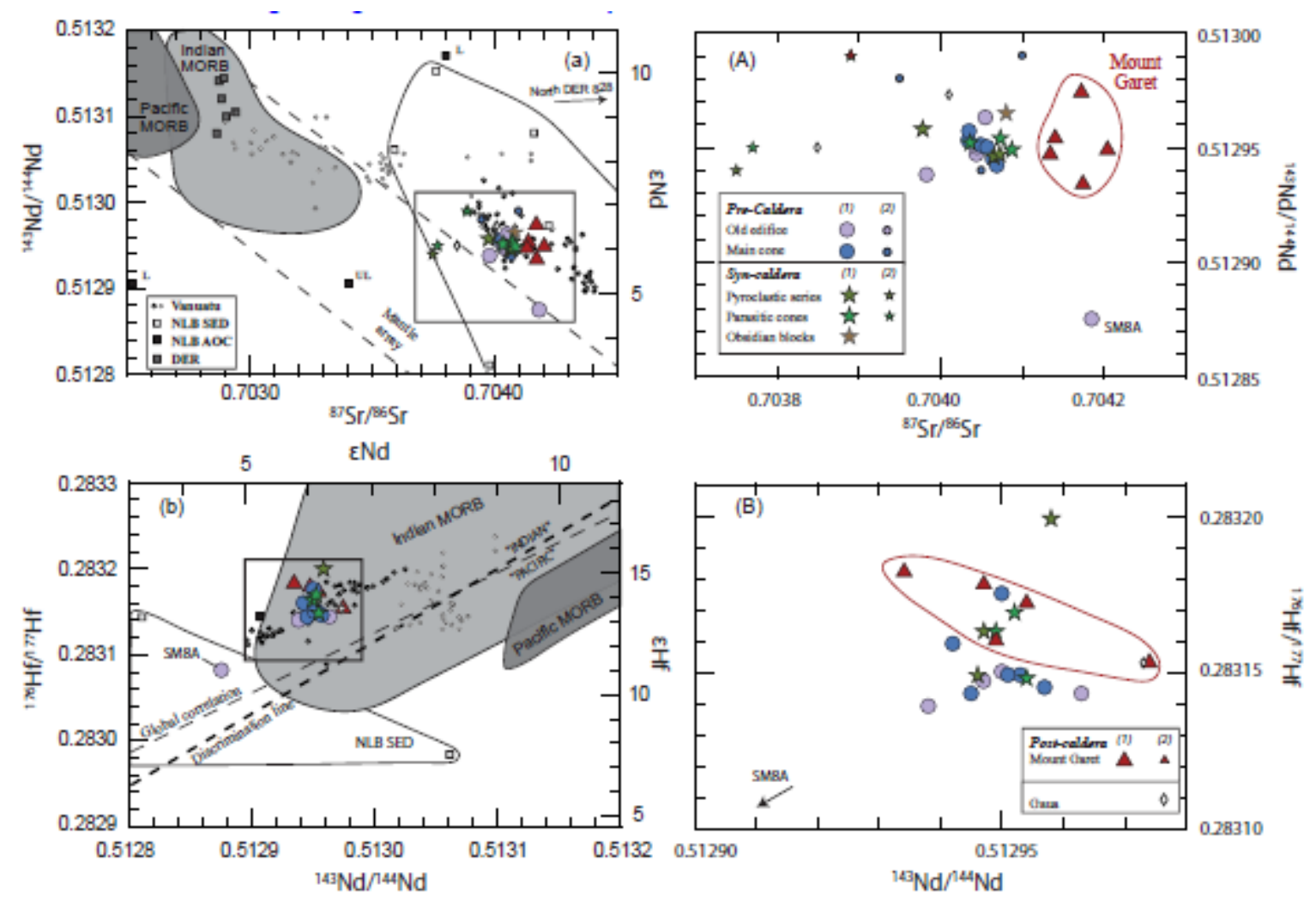

Figure 9 

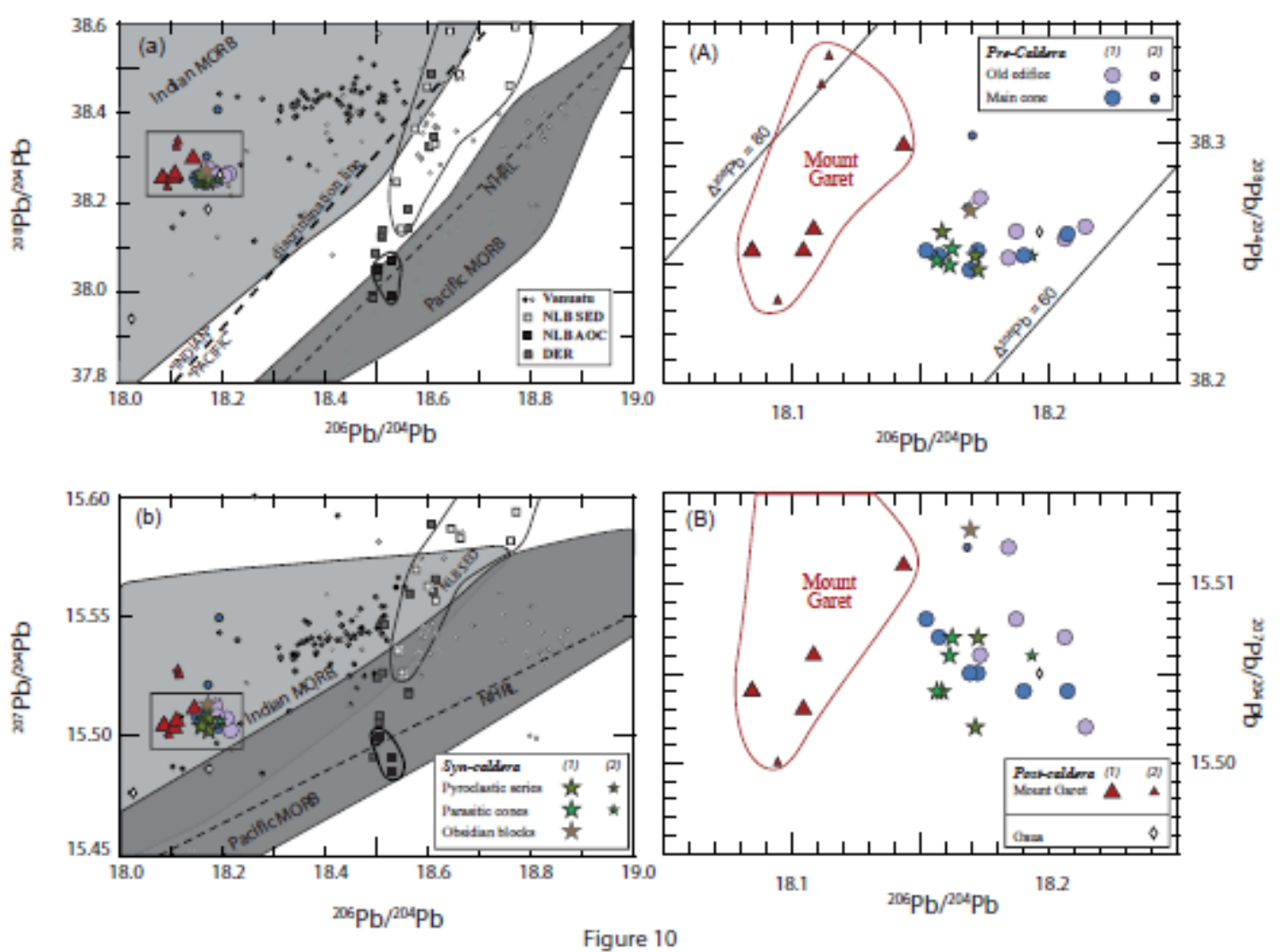


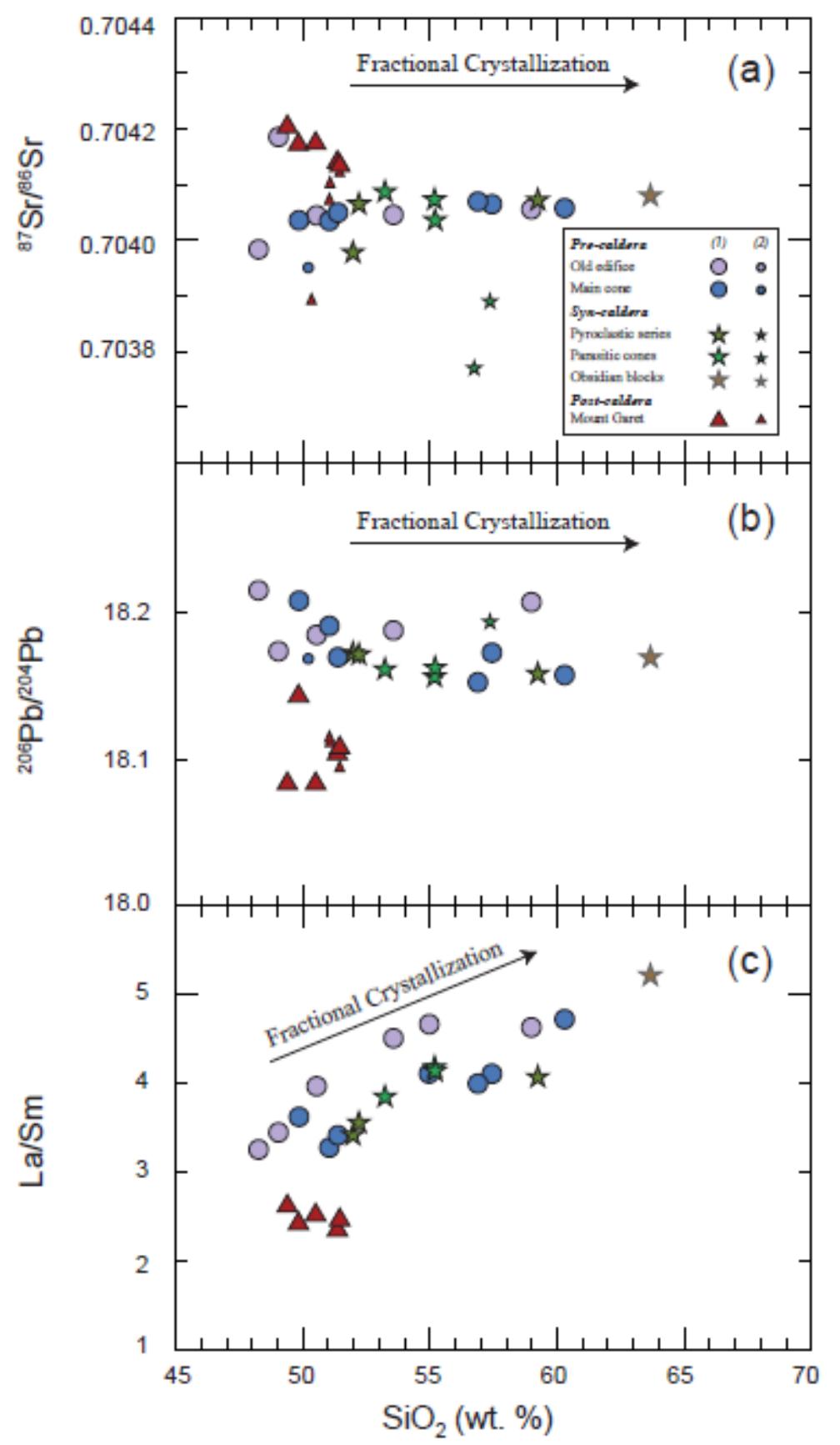

Figure 11 


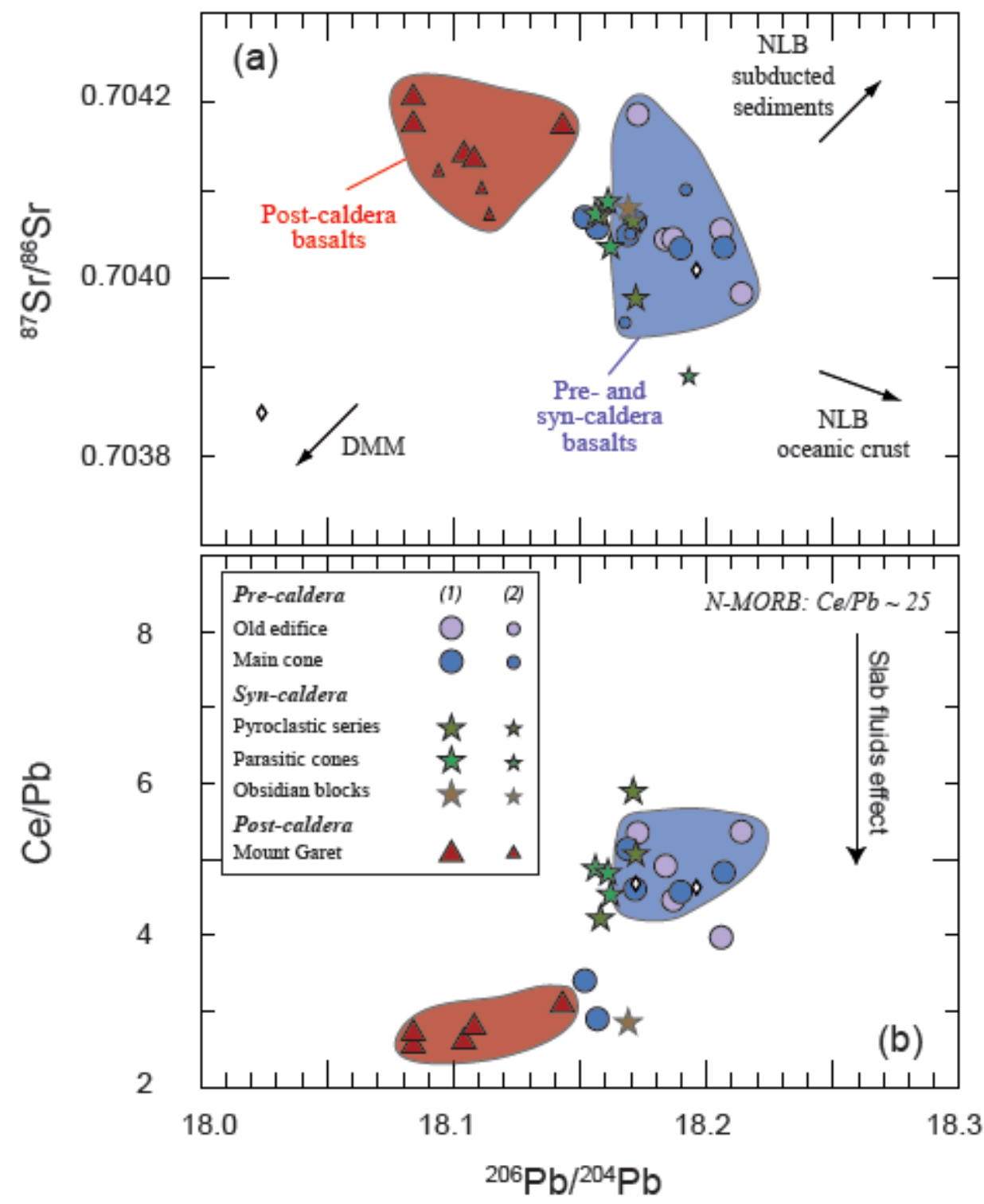

Figure 12 

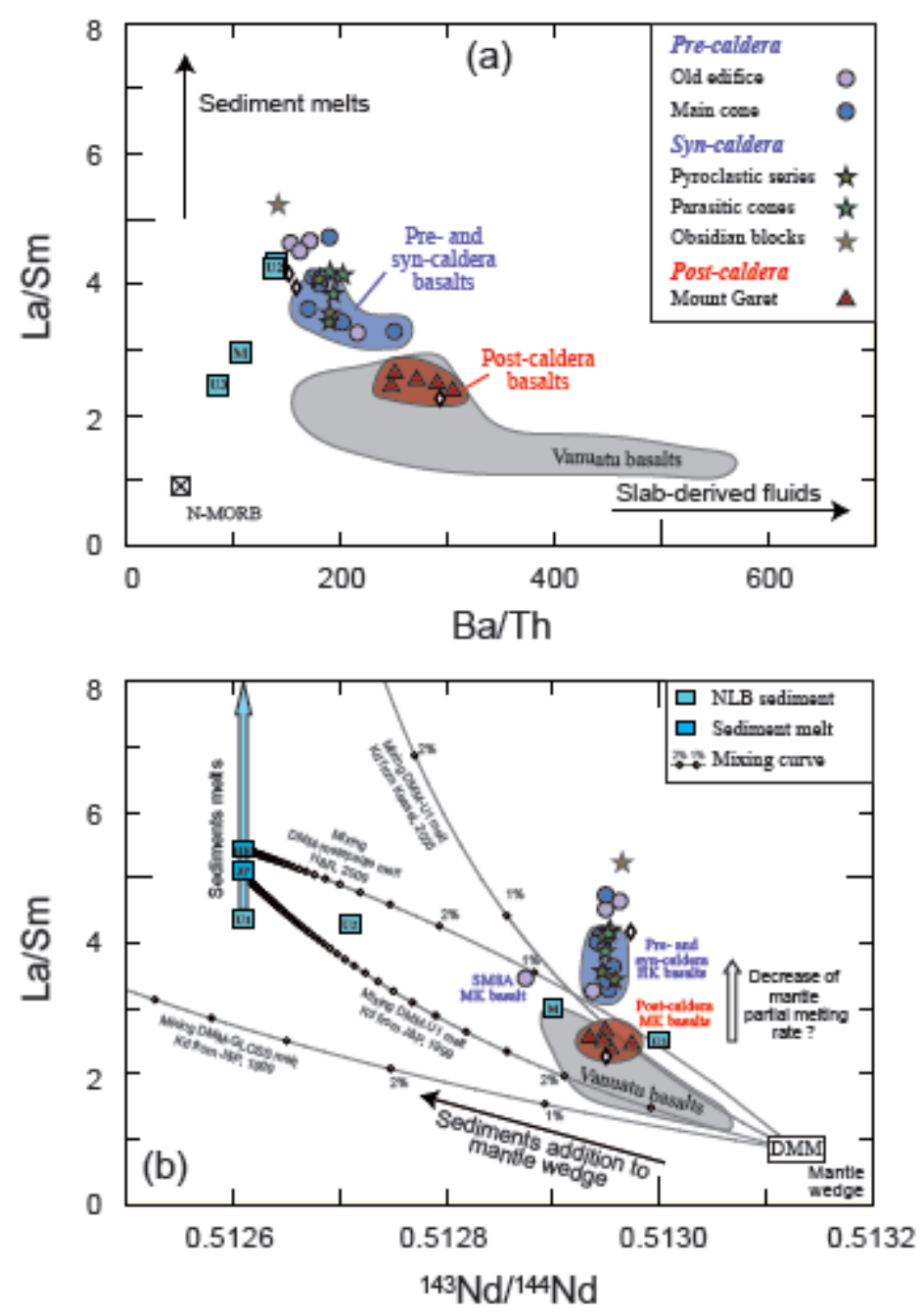

Figure 13 


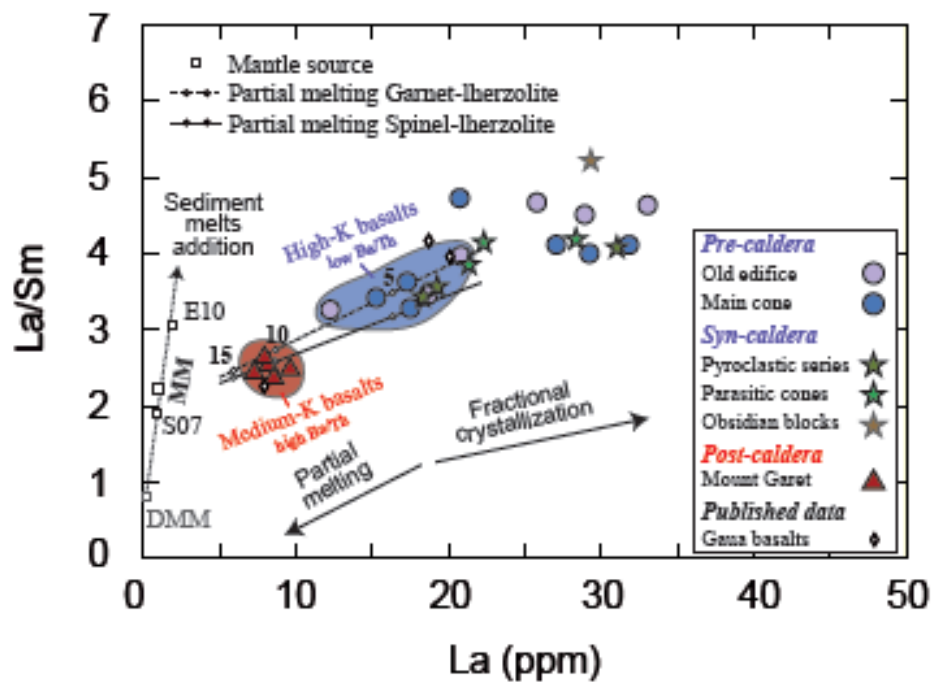

Figure 14 
Table 1: Isotope ratios, major and trace element content for the Gaua lavas

\section{Pre- caldera}

\begin{tabular}{|c|c|c|c|c|c|c|c|c|c|c|c|c|c|}
\hline \multirow[b]{2}{*}{ Sample Rock } & \multicolumn{6}{|c|}{ Old massif } & \multicolumn{7}{|c|}{ Main cone } \\
\hline & SM8A' & $\begin{array}{l}\text { SM8E }^{2} \\
\end{array}$ & SM 9A & SM9B & SM1181 & SM1182 & $\operatorname{SM} 2 A^{2}$ & SM 2B & SM8B $^{2}$ & $\begin{array}{ll}\text { SM15C } \\
\text { SM }\end{array}$ & SM17A & $\begin{array}{l}\text { SM27 } \\
\end{array}$ & SM 57 \\
\hline type & lava flow & lava block & lava flow & lava block & lava block & lava block & lava flow & lava flow & radial dyke & lava flow & lava flow & old andesite & e lava flow \\
\hline Details & & in a river & - & $\begin{array}{l}\text { on the } \\
\text { beach }\end{array}$ & Devil Rock & Devil Rock & under SM2B & $\begin{array}{l}\text { under the } \\
\text { pyroclastic } \\
\text { series }\end{array}$ & - & $\begin{array}{l}\text { under the } \\
\text { pyroclastic } \\
\text { series }\end{array}$ & $\begin{array}{l}\text { under the } \\
\text { pyroclastic } \\
\text { series }\end{array}$ & $\begin{array}{l}\text { south coast } \\
\text { of the Lake } \\
\text { Letas }\end{array}$ & \\
\hline Latitude & S $14^{\circ} 21^{\prime} 9^{\prime \prime}$ & S14" $219^{\prime \prime}$ & $S_{14^{\circ} 19^{\prime} 36^{\prime \prime}}$ & $S 14^{\circ} 19^{\prime} 36^{\prime \prime}$ & $\mathrm{S}_{14^{\circ} 15^{\prime} 28^{\prime \prime}}$ & 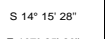 & S 1 14 $21^{\circ} 1^{45^{\prime \prime}}$ & $\mathrm{S} 14^{\circ} 21^{\prime} 45^{\prime \prime}$ & $\mathrm{S} 14^{\circ} 21^{\prime \prime \prime}$ & $\mathrm{S} 14^{\circ} 1^{\prime} 9^{9^{\circ}}$ & $S 14^{\circ} 12^{2} \cdot 4^{\prime \prime}$ & $\mathrm{S} 14^{\circ} \mathbf{1}^{\circ} 8^{\prime 22^{\prime \prime}}$ & $\mathrm{S} 14^{\circ} 16^{\prime} 25^{\prime \prime}$ \\
\hline Longitude & E $167^{\circ} 25^{\prime} 54^{\prime \prime}$ & E $167^{\circ} 25^{\circ} 54^{\prime \prime}$ & E $167^{\circ} 26^{\prime} 16^{\prime \prime}$ & & E $166^{\circ} 25^{\circ} 26^{\prime \prime}$ & E $167^{\circ} 25^{\prime 2} 26^{\prime \prime}$ & E $167^{\circ} 33^{3} 44^{\prime \prime}$ & E $167^{\circ} 33^{\prime} 44^{\prime \prime}$ & & & & & \\
\hline \multicolumn{14}{|l|}{ wt. \% } \\
\hline $\mathrm{SiO}_{2}$ & 49.06 & 48.28 & 59.01 & 54.99 & 50.56 & 53.58 & 51.06 & 57.45 & 49.87 & 51.40 & 54.98 & 60.31 & 56.90 \\
\hline $\mathrm{TiO}_{2}$ & 0.80 & 0.73 & 0.67 & 0.75 & 0.83 & 0.88 & 0.85 & 0.87 & 0.83 & 0.76 & 0.82 & 0.76 & 0.90 \\
\hline $\mathrm{Al}_{2} \mathrm{O}_{3}$ & 13.34 & 12.14 & 19.08 & 17.20 & 15.53 & 16.80 & 18.59 & 16.93 & 15.32 & 16.61 & 17.55 & 16.98 & 16.72 \\
\hline $\mathrm{Fe}_{2} \mathrm{O}_{3}(\mathrm{t})$ & 12.07 & 12.40 & 7.02 & 9.00 & 11.65 & 10.01 & 11.04 & 9.19 & 12.31 & 10.60 & 9.17 & 7.30 & 8.79 \\
\hline $\mathrm{MnO}$ & 0.21 & 0.20 & 0.17 & 0.20 & 0.21 & 0.21 & 0.24 & 0.24 & 0.22 & 0.20 & 0.23 & 0.13 & 0.24 \\
\hline $\mathrm{MgO}$ & 8.53 & 10.59 & 0.79 & 3.00 & 5.08 & 3.36 & 4.07 & 1.71 & 6.11 & 4.88 & 2.51 & 1.33 & 2.09 \\
\hline $\mathrm{CaO}$ & 12.39 & 12.48 & 2.62 & 6.43 & 10.15 & 7.03 & 8.51 & 4.11 & 10.84 & 10.32 & 6.42 & 3.87 & 4.97 \\
\hline $\mathrm{Na}_{2} \mathrm{O}$ & 2.39 & 1.89 & 5.47 & 4.52 & 3.19 & 4.04 & 3.44 & 4.95 & 2.45 & 3.15 & 4.45 & 4.87 & 4.94 \\
\hline $\mathrm{K}_{2} \mathrm{O}$ & 0.74 & 1.05 & 4.71 & 3.46 & 2.34 & 3.42 & 1.88 & 3.86 & 1.74 & 1.76 & 3.33 & 4.05 & 3.85 \\
\hline $\mathrm{P}_{2} \mathrm{O}_{5}$ & 0.47 & 0.24 & 0.46 & 0.45 & 0.46 & 0.67 & 0.30 & 0.68 & 0.31 & 0.33 & 0.55 & 0.41 & 0.60 \\
\hline LOI & 1.96 & 0.55 & 1.99 & 0.09 & 0.51 & 1.33 & 1.58 & 0.86 & 2.07 & 0.09 & -0.04 & 0.96 & -0.29 \\
\hline Total & 100.41 & 100.18 & 99.60 & 100.10 & 99.80 & 100.24 & 100.29 & 100.07 & 100.33 & 100.87 & 100.54 & 99.62 & 99.88 \\
\hline \multicolumn{14}{|l|}{$p p m$} \\
\hline Sc & 38 & 43 & 8 & 15 & 26 & 16 & 20 & & 35 & 2 & 12 & & 10 \\
\hline v & 335 & 340 & 110 & 245 & 322 & 320 & 334 & 192 & 325 & 320 & 240 & 172 & 200 \\
\hline $\mathrm{Cr}$ & 305 & 275 & 3 & 10 & 60 & 7 & 2 & & 125 & 8 & 2 & & 2 \\
\hline Co & 45 & 53 & 14 & 25 & 37 & 27 & 33 & 21 & 42 & 3 & 21 & & 10 \\
\hline $\mathrm{Ni}$ & 80 & 125 & 3 & 11 & 23 & 14 & 11 & 2 & 35 & 3 & 4 & & 4 \\
\hline Li & 9.2 & 7.1 & 18.2 & 16.7 & 11.8 & 15.6 & 22.9 & 15.6 & 16.6 & 10.0 & 15.0 & 16.7 & 15.3 \\
\hline $\mathrm{Rb}$ & 3.77 & 12.7 & 75.8 & 58.2 & 43.4 & 63.7 & 23.4 & 64.6 & 24.0 & 26.5 & 51.3 & 63.8 & 59.2 \\
\hline $\mathrm{sr}$ & 845 & 650 & 632 & 769 & 958 & 847 & 892 & 694 & 722 & 865 & 914 & 584 & 726 \\
\hline$Y$ & 17.8 & 16.2 & 25.3 & 25.3 & 19.9 & 25.5 & 25.5 & 32.8 & 19.4 & 19.5 & 27.7 & 22.1 & 31.3 \\
\hline $\mathrm{Zr}$ & 86 & & 165 & 124 & 88 & 126 & 77 & 150 & 77 & 7 & 124 & 153 & 140 \\
\hline $\mathrm{Nb}$ & 1.72 & 0.90 & 3.90 & 2.92 & 2.00 & 2.97 & 1.53 & 3.43 & 1.66 & 1.51 & 2.74 & 3.26 & 3.15 \\
\hline Cs & 0.12 & 0.14 & 0.26 & 0.28 & 0.52 & 0.87 & 0.07 & 0.28 & 1.24 & 0.17 & 0.34 & 0.56 & 0.40 \\
\hline $\mathrm{Ba}$ & 483 & 309 & 912 & 743 & 539 & 722 & 571 & 892 & 439 & 441 & 759 & 958 & 869 \\
\hline La & 18.7 & 12.3 & 33.1 & 25.8 & 20.9 & 29.0 & 17.5 & 31.9 & 17.3 & 15.3 & 27.1 & 20.8 & 29.3 \\
\hline $\mathrm{Ce}$ & 39.4 & 22.9 & 58.8 & 49.0 & 41.7 & 57.3 & 34.7 & 65.4 & 35.0 & 32.1 & 53.3 & 39.1 & 60.2 \\
\hline $\mathrm{Pr}$ & 5.34 & 3.54 & 8.96 & 6.49 & 5.66 & 7.50 & 5.24 & 8.71 & 4.85 & 4.45 & 7.39 & 4.95 & 8.09 \\
\hline $\mathrm{Nd}$ & 23.6 & 16.3 & 35.7 & 27.0 & 24.7 & 31.6 & 23.6 & 36.7 & 21.5 & 19.7 & 31.5 & 20.8 & 34.0 \\
\hline $\mathrm{Sm}$ & 5.42 & 3.77 & 7.15 & 5.54 & 5.26 & 6.43 & 5.35 & 7.76 & 4.78 & 4.48 & 6.60 & 4.40 & 7.33 \\
\hline Eu & 1.66 & 1.19 & 1.80 & 1.60 & 1.59 & 1.84 & 1.65 & 2.10 & 1.43 & 1.38 & 1.88 & 1.65 & 2.03 \\
\hline Gd & 4.90 & 3.60 & 5.58 & 4.87 & 4.76 & 5.58 & 4.89 & 6.53 & 4.36 & 4.15 & 5.67 & 3.89 & 6.75 \\
\hline $\mathrm{Tb}$ & 0.63 & 0.49 & 0.79 & 0.68 & 0.62 & 0.75 & 0.69 & 0.94 & 0.59 & 0.58 & 0.80 & 0.57 & 0.95 \\
\hline Dy & 3.51 & 2.89 & 4.61 & 4.08 & 3.62 & 4.48 & 4.23 & 5.68 & 3.50 & 3.50 & 4.92 & 3.69 & 5.59 \\
\hline Ho & 0.64 & 0.57 & 0.91 & 0.83 & 0.73 & 0.89 & 0.85 & 1.15 & 0.69 & 0.71 & 0.97 & $\begin{array}{l}0.78 \\
0.78\end{array}$ & $\begin{array}{l}1.13 \\
1.13\end{array}$ \\
\hline Er & 1.74 & 1.57 & 2.70 & 2.40 & 2.01 & 2.55 & 2.43 & 3.38 & 1.95 & 2.03 & 2.76 & 2.31 & 3.29 \\
\hline $\mathrm{Yb}$ & 1.53 & 1.39 & 2.71 & 2.39 & 1.85 & 2.42 & 2.21 & 3.26 & 1.79 & 1.92 & 2.66 & 2.50 & 3.12 \\
\hline Lu & 0.22 & 0.20 & 0.40 & 0.35 & 0.28 & 0.36 & 0.33 & 0.49 & 0.27 & 0.29 & 0.40 & 0.38 & 0.47 \\
\hline Hf & 2.33 & 1.54 & 4.19 & 3.24 & 2.42 & 3.26 & 2.31 & 4.02 & 2.21 & 2.08 & 3.42 & 4.08 & 3.84 \\
\hline $\mathrm{Ta}$ & 0.09 & 0.05 & 0.22 & 0.15 & 0.10 & 0.15 & 0.09 & 0.18 & 0.09 & 0.09 & 0.14 & 0.17 & 0.18 \\
\hline $\mathrm{Pb}$ & 7.4 & 4.3 & 14.8 & 10.6 & 8.5 & 12.9 & 7.6 & 14.2 & 7.3 & 6.3 & 11.2 & 13.5 & 17.7 \\
\hline Th & 2.43 & 1.43 & 5.94 & & 2.84 & 4.45 & 2.28 & 5.11 & 2.58 & 2.18 & 4.15 & 5.05 & 4.80 \\
\hline u & 0.70 & 0.47 & 2.22 & 1.62 & 1.08 & 1.67 & 0.68 & 1.93 & 0.49 & 0.67 & 1.00 & 1.93 & 1.83 \\
\hline \multicolumn{14}{|l|}{ Isotopes } \\
\hline $\begin{array}{l}{ }^{87} \mathrm{Sr} /^{86} \mathrm{Sr} \\
2 \sigma\end{array}$ & 0.704185 & 0.703983 & 0.704055 & & $\begin{array}{l}0.704044 \quad 8 \\
8\end{array}$ & 0.704045 & 0.704034 & 0.704064 & 0.704035 & 0.704049 & & 0.704057 & 6 \\
\hline${ }^{143} \mathrm{Nd} /{ }^{144} \mathrm{Nd}$ & 0.512875 & 0.512938 & 2963 & & 0.512947 & 0.51295 & 0.512953 & 0.512945 & 0.512957 & 0.512951 & & 0.51295 & 0.512942 \\
\hline & ${ }_{4.62}^{8}$ & 5.85 & 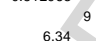 & & 6.03 & $6.09^{5}$ & 6.14 & $5.99^{10}$ & $6.22^{8}$ & 611 & & 609 & $\begin{array}{ll}8 & 17\end{array}$ \\
\hline${ }^{206} \mathrm{~Pb} /{ }^{204} \mathrm{~Pb}$ & 18.173 & 18.214 & 18.206 & & 18.184 & 18.187 & 18.190 & 18.172 & $\begin{array}{r}6.22 \\
18.207\end{array}$ & $\begin{array}{r}6.11 \\
18.169\end{array}$ & & 18.157 & 18.152 \\
\hline & 1 & 1 & & & 1 & & 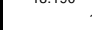 & 1 & 1 & & & 10.100 & 1 \\
\hline $\begin{array}{l}{ }^{207} \mathrm{~Pb} /{ }^{204} \mathrm{~Pb} \\
2 \sigma\end{array}$ & 15.506 & 15.502 & 15.507 & & 15.512 & ${ }_{15.508}$ & 15.504 & ${ }_{1}^{15.505}$ & 15.504 & 15.505 & & 15.507 & 15.508 \\
\hline${ }^{208} \mathrm{~Pb} /{ }^{204} \mathrm{~Pb}$ & 38.277 & 38.265 & 38.260 & & 38.252 & 38.263 & 38.253 & 38.255 & 38.262 & 38.247 & & 38.253 & 38.255 \\
\hline & & 2 & 2 & & 2 & 2 & 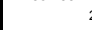 & 2 & 1 & & & & 1 \\
\hline${ }^{176} \mathrm{Hf} / \mathrm{f}^{177} \mathrm{HF}$ & 0.283081 & 0.283139 & 0.283143 & & 0.283147 & 0.283150 & 0.283149 & 0.283143 & 0.283145 & 0.283149 & & 0.283175 & 0.283159 \\
\hline $\begin{array}{l}2 \sigma \\
\varepsilon \mathrm{Hf}\end{array}$ & $10.9^{3}$ & $13.0^{4}$ & 13.1 & & $13.3^{4}$ & $13.4^{4}$ & 13.3 & 13.1 & 132 & 13.3 & & $14.2^{5}$ & $13.7^{3}$ \\
\hline
\end{tabular}




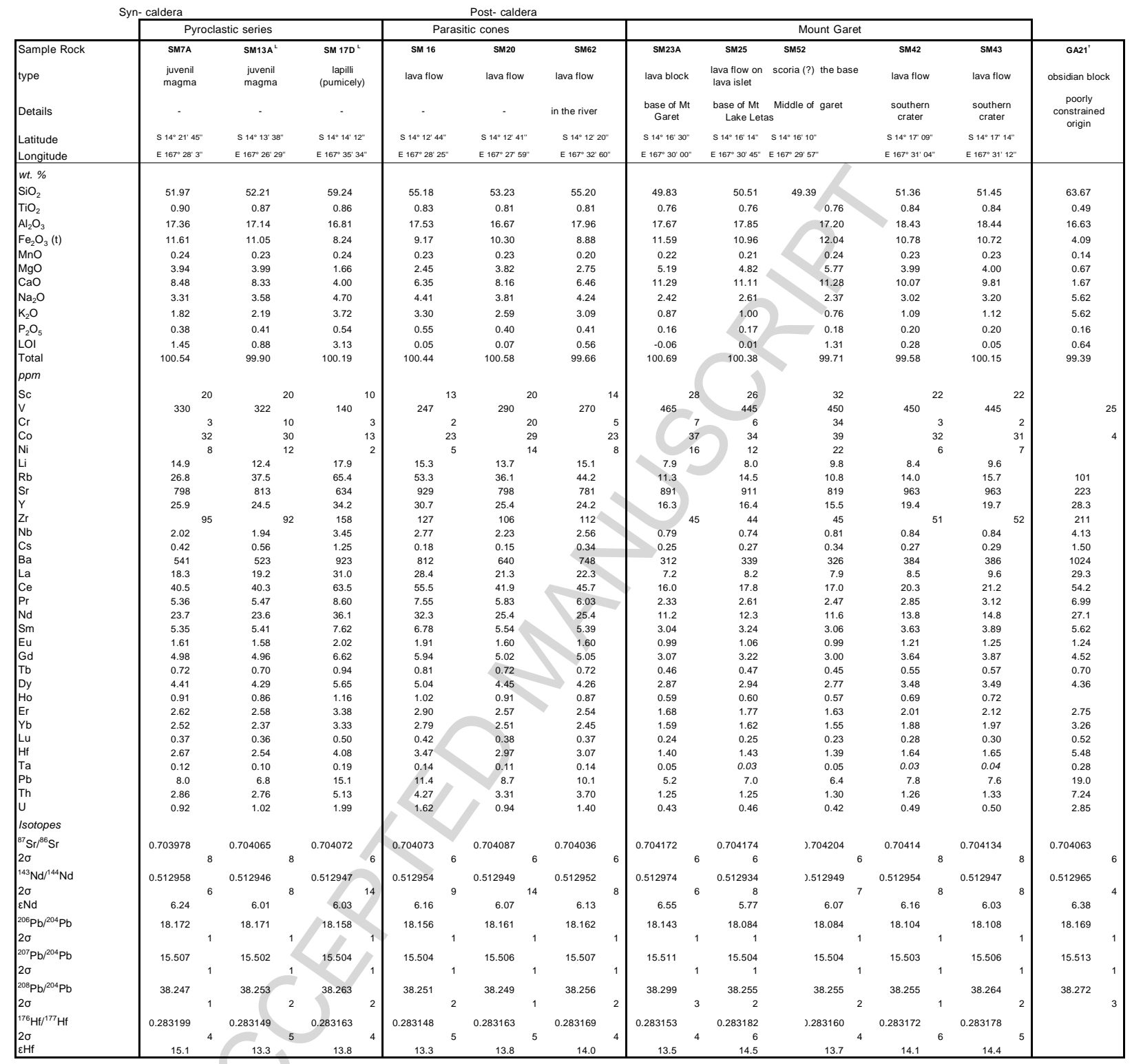


Table 2

Fractional crystallization model parameters

Model

Stage

Initial $\mathrm{SiO}_{2}$ initial

Final

$\Delta \mathrm{SiO}_{2}$

Mineral assemblage (\%)

$\%$

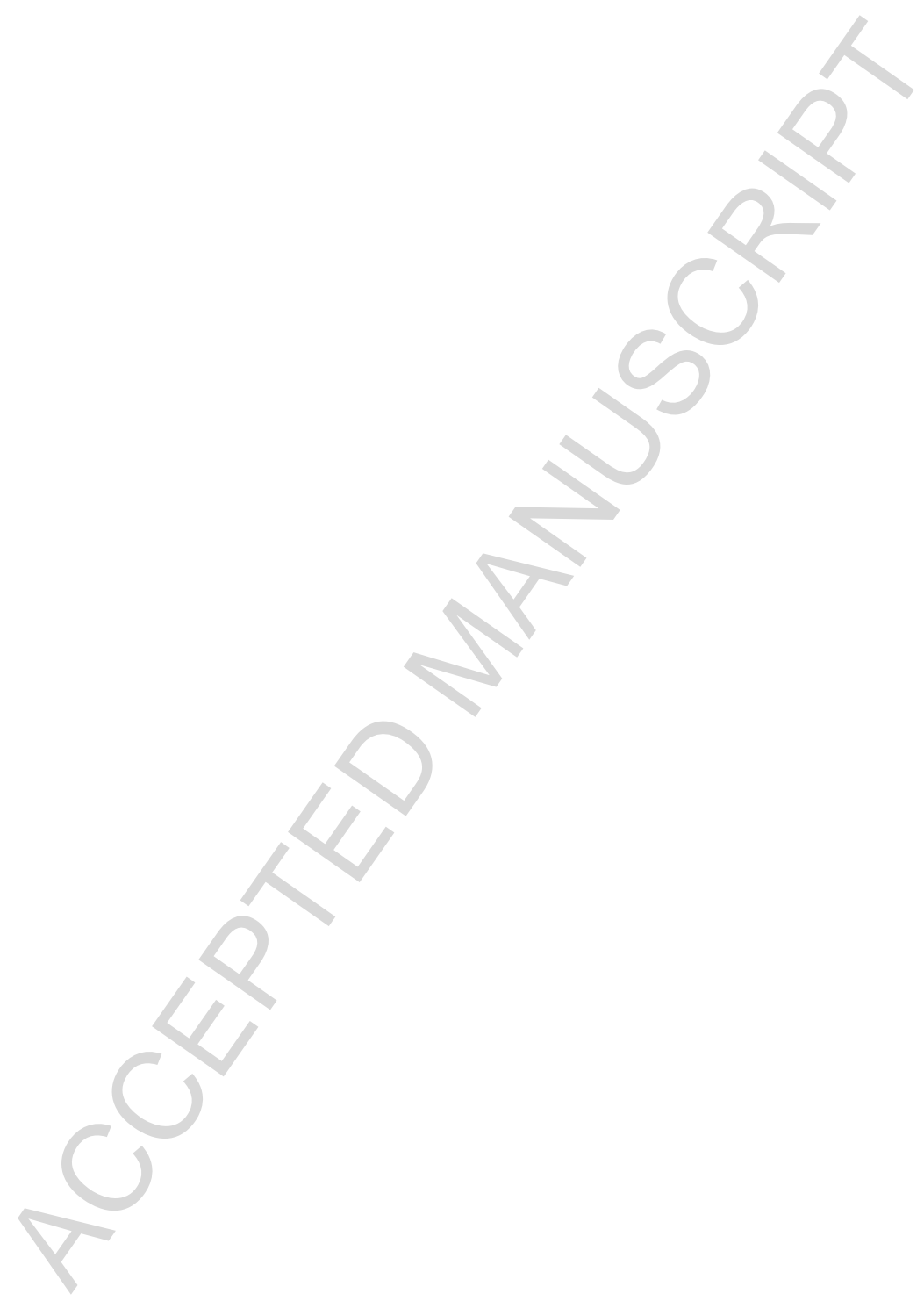




\begin{tabular}{|c|c|c|c|c|c|c|c|c|c|c|c|}
\hline \# & & parent & (wt. \%) & daughter & (wt. \%) & & $\mathrm{Ol}$ & Cpx & $\mathrm{PI}$ & Ox & crystallized \\
\hline 1 & overall medium $-\mathrm{K}_{2} \mathrm{O}$ lavas & SM52 & 48.60 & SM43 & 2.90 & 0.07 & 8.3 & 54.4 & 27.7 & 9.6 & 23 \\
\hline 2 & $\begin{array}{c}\text { overall medium }-\mathrm{K}_{2} \mathrm{O} \text { lavas } \\
\text { to high- } \mathrm{K}_{2} \mathrm{O} \text { lavas }\end{array}$ & SM52 & 48.60 & GA21 & 14.28 & 1.56 & 5.0 & 41.2 & 42.7 & 11.1 & 67 \\
\hline 3 & overall high- $\mathrm{K}_{2} \mathrm{O}$ lavas & SM8E & 48.10 & GA21 & 15.07 & 0.23 & 11.6 & 61.1 & 20.0 & 7.3 & 75 \\
\hline \multirow[t]{4}{*}{4} & high- $\mathrm{K}_{2} \mathrm{O}$ lavas: 3 -stages & & & & & & & & & & \\
\hline & 1 & SM8E & 48.10 & SM2A & 2.30 & 0.04 & 14.2 & 81 & 0.8 & 3.2 & 48 \\
\hline & 2 & SM2A & 50.40 & SM62 & 4.30 & 0.16 & 15.9 & 17.5 & 57.2 & 9.4 & 71 \\
\hline & 3 & SM62 & 54.70 & GA21 & 8.97 & 0.26 & 4.4 & 18.4 & 66.4 & 10.7 & 52 \\
\hline
\end{tabular}


Table 3

Parameters of mixing models

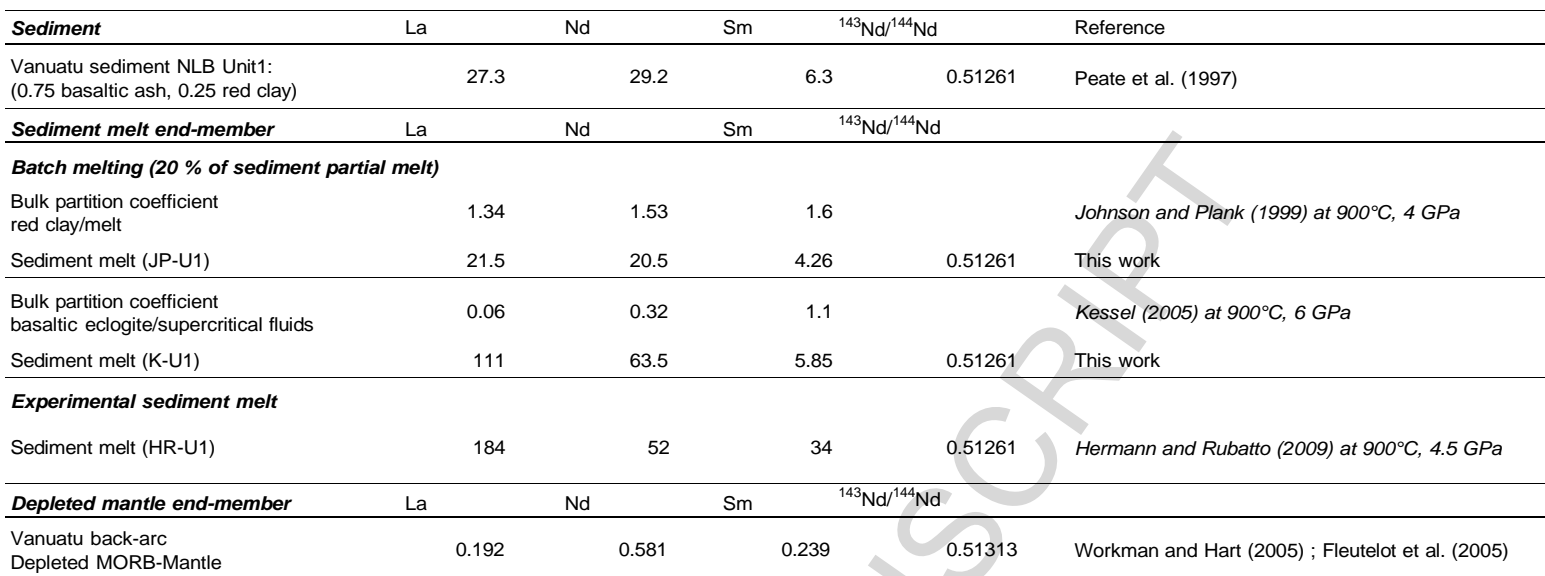


Table 4

Non-modal batch melting model parameters used in melting models

Mantle mineralogy

\begin{tabular}{|c|c|c|c|c|c|c|}
\hline & Olivine & Orthopyroxene & Clinopyroxene & Garnet & or & Spinel \\
\hline Source mode & 0.57 & 0.23 & 0.15 & & 0.05 & \\
\hline P (melt mode) & 0.05 & 0.05 & 0.81 & & 0.09 & \\
\hline Kd La & 0.00005 & 0.0006 & 0.047 & 0.0005 & or & 0.0006 \\
\hline Kd Sm & 0.001 & 0.011 & 0.22 & 0.17 & or & 0.001 \\
\hline
\end{tabular}

Mantlecomposition

\begin{tabular}{|c|c|c|c|c|}
\hline & \\
\hline & Depleted MORB-Mantle & & etasomatized Mant & \\
\hline & $\begin{array}{l}\text { Workman and Hart (2005) } \\
\text { (DMM) }\end{array}$ & $\begin{array}{l}\text { Singer et al. (2007) } \\
\text { (S07) }\end{array}$ & $\begin{array}{c}\text { Ersoy et al. (2010) } \\
\text { (E10) }\end{array}$ & $\begin{array}{l}\text { This study } \\
\text { (MM) }\end{array}$ \\
\hline La (ppm) & 0.192 & 0.82 & 1.87 & 0.9 \\
\hline Sm (ppm) & 0.239 & 0.43 & 0.61 & 0.4 \\
\hline
\end{tabular}

